\title{
Nocturnal isoprene oxidation over the Northeast United States in summer and its impact on reactive nitrogen partitioning and secondary organic aerosol
}

\author{
S. S. Brown ${ }^{1}$, J. A. deGouw ${ }^{1,2}$, C. Warneke ${ }^{1,2}$, T. B. Ryerson ${ }^{1}$, W. P. Dubé ${ }^{1,2}$, E. Atlas ${ }^{3}$, R. J. Weber ${ }^{4}$, R. E. Peltier, , \\ J. A. Neuman ${ }^{1,2}$, J. M. Roberts ${ }^{1}$, A. Swanson ${ }^{2,5, * *}$, F. Flocke ${ }^{5}$, S. A. McKeen ${ }^{1,2}$, J. Brioude ${ }^{1,2}$, R. Sommariva ${ }^{1,2, * * *}$, \\ M. Trainer ${ }^{1}$, F. C. Fehsenfeld ${ }^{1,2}$, and A. R. Ravishankara ${ }^{1}$ \\ ${ }^{1}$ NOAA Earth System Research Laboratory, 325 Broadway, Boulder, CO 80305, USA \\ ${ }^{2}$ Cooperative Institute for Research in Environmental Sciences, University of Colorado, Boulder, CO 80309, USA \\ ${ }^{3}$ RSMAS/MAC, University of Miami, 4600 Rickenbacker Causeway, Miami, FL 33149, USA \\ ${ }^{4}$ School of Earth and Atmospheric Sciences, Georgia Institute of Technology, Atlanta, GA 30332, USA \\ ${ }^{5}$ National Center for Atmospheric Research, 1850 Table Mesa Dr., Boulder, CO 80305, USA \\ * currently at: Department of Environmental Medicine, NYU School of Medicine, Tuxedo, NY 10987, USA \\ ** currently at: Chemical Technology Department, Northrup Grumman Space Technology, Redondo Beach, CA 90278, USA \\ ${ }^{* * * *}$ currently at: School of Environmental Sciences, University of East Anglia, Norwich, NR4 7TJ, UK
}

Received: 20 October 2008 - Published in Atmos. Chem. Phys. Discuss.: 6 January 2009

Revised: 30 March 2009 - Accepted: 30 April 2009 - Published: 11 May 2009

\begin{abstract}
Isoprene is the largest single VOC emission to the atmosphere. Although it is primarily oxidized photochemically during daylight hours, late-day emissions that remain in the atmosphere at sunset undergo oxidation by $\mathrm{NO}_{3}$ in regionally polluted areas with large $\mathrm{NO}_{\mathrm{x}}$ levels. A recent aircraft study examined isoprene and its nocturnal oxidants in a series of night flights across the Northeast US, a region with large emissions of both isoprene and $\mathrm{NO}_{\mathrm{x}}$. Substantial amounts of isoprene that were observed after dark were strongly anticorrelated with measured $\mathrm{NO}_{3}$ and were the most important factor determining the lifetime of this radical. The products of photochemical oxidation of isoprene, methyl vinyl ketone and methacrolein, were more uniformly distributed, and served as tracers for the presence of isoprene at sunset, prior to its oxidation by $\mathrm{NO}_{3}$. A determination of the mass of isoprene oxidized in darkness showed it to be a large fraction (>20\%) of emitted isoprene. Organic nitrates produced from the $\mathrm{NO}_{3}+$ isoprene reaction, though not directly measured, were estimated to account for $2-9 \%$ of total reactive nitrogen. The mass of isoprene oxidized by $\mathrm{NO}_{3}$ was comparable to and correlated with the organic aerosol
\end{abstract}

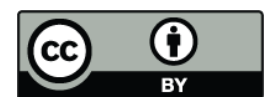

Correspondence to: S. S. Brown (steven.s.brown@noaa.gov) loading for flights with relatively low organic aerosol background. The contribution of nocturnal isoprene oxidation to secondary organic aerosol was determined in the range 1$17 \%$, and isoprene $\mathrm{SOA}$ mass derived from $\mathrm{NO}_{3}$ was calculated to exceed that due to $\mathrm{OH}$ by approximately $50 \%$.

\section{Introduction}

Isoprene is the most important biogenically emitted VOC (440-660 $\mathrm{Tg} \mathrm{C} \mathrm{yr}^{-1}$ globally, Guenther et al., 2006) and is important in regulating levels of tropospheric oxidants such as ozone and $\mathrm{OH}$ (Lelieveld et al., 2008; Poisson et al., 2000; Trainer et al., 1987) and in the formation of secondary organic aerosol (Claeys et al., 2004; Henze and Seinfeld, 2006). Emissions of isoprene from the terrestrial biosphere are dependent on season, temperature and sunlight (Fuentes et al., 2000), such that the majority of isoprene emissions occur at warm temperatures and during daylight hours. Because isoprene emissions are approximately coincident in time with the photochemical generation of $\mathrm{OH}$ radicals, and because of the reactivity of isoprene with $\mathrm{OH}(1.4 \mathrm{~h}$ lifetime for $[\mathrm{OH}]=2 \times 10^{6}$ molecules $\mathrm{cm}^{3}$, Atkinson and Arey, 2003),

Published by Copernicus Publications on behalf of the European Geosciences Union. 
the majority of emitted isoprene undergoes rapid photochemical oxidation.

Isoprene that is emitted late in the day, particularly during the late afternoon as $\mathrm{OH}$ concentrations begin to fall, will not be fully oxidized photochemically and can remain in the nighttime atmosphere. Ozonolysis typically consumes less than 50\%, of this isoprene (Atkinson and Arey, 2003), allowing for overnight transport and oxidation on the following day. In polluted areas however, the presence of $\mathrm{NO}_{\mathrm{x}}$ leads to the formation of the nitrate radical, $\mathrm{NO}_{3}$, which is also a strong oxidant toward isoprene (Winer et al., 1984). This radical is unstable in sunlight, but at night its presence leads to an estimated lifetime for isoprene that is similar to that predicted for photochemical oxidation (Atkinson and Arey, 2003). If the nocturnal production rate of $\mathrm{NO}_{3}$ is sufficient, and if the level of $\mathrm{NO}_{\mathrm{x}}$ in a nighttime air mass exceeds that of isoprene itself, then reaction with $\mathrm{NO}_{3}$ will lead to complete consumption of isoprene overnight. The presence of $\mathrm{NO}_{\mathrm{x}}$ pollution thus represents an anthropogenic perturbation on the isoprene oxidation cycle.

The size of this $\mathrm{NO}_{\mathrm{x}}$ perturbation depends on the fraction of the diurnal isoprene emission that remains in the atmosphere at sunset and the spatial overlap of this isoprene with anthropogenic $\mathrm{NO}_{\mathrm{x}}$ emissions. Recent model estimates that consider global or continental averages place the fraction of total isoprene emissions that are oxidized by $\mathrm{NO}_{3}$ at $6 \%$ of North American (Horowitz et al., 2007) and 6-7\% of global isoprene emissions ( $\mathrm{Ng}$ et al., 2008). Even though these figures are a small fraction of total isoprene emissions, they nevertheless represent a large mass on a global scale (e.g. 22-29 Tg of isoprene consumed by this reaction annually, $\mathrm{Ng}$ et al., 2008). If such estimates are correct, they represent a significant fraction of oxidized nitrogen consumption as well (4.5-6.0 Tg N annually, or 12-16\% of year 2000 global anthropogenic $\mathrm{NO}_{\mathrm{x}}$ emissions, Olivier and Berdowski, 2001).

Despite the large isoprene mass oxidized via $\mathrm{NO}_{3}$ reaction, the resulting products have not been widely studied. The reaction is known to produce unsaturated organic nitrates with a yield of approximately $80 \%$ as first-generation products (Barnes et al., 1990). These nitrates consist of unsaturated hydroxy-, hydroperoxy- and carbonyl nitrates (Kwok et al., 1996; Skov et al., 1992, 1994; Tuazon et al., 1999; Berndt and Boge, 1997), with a recent study also showing evidence for formation of dinitrates and oligomers ( $\mathrm{Ng}$ et al., 2008). The subsequent fates of such compounds are poorly understood and are an important uncertainty in isoprene oxidation models (Fan and Zhang, 2004; Paulson and Seinfeld, 1992). These uncertainties may reduce the accuracy of modeled transport and/or loss of reactive nitrogen or of modeled surface level ozone (Horowitz et al., 2007; von Kuhlmann et al., 2004). Recently, Ng et al. (2008) measured mass yields of secondary organic aerosol from the oxidation of isoprene by $\mathrm{NO}_{3}$ to be in the range $5-25 \%$, much larger than that from $\mathrm{OH}\left(1-3 \%\right.$, Kroll et al., 2005) or $\mathrm{O}_{3}(<1 \%$, Kleindienst et al., 2007) reactions, and estimated the contribution of this reaction to global secondary organic aerosol production at 2-3 $\mathrm{Tg} \mathrm{yr}^{-1}$.

Several recent surface-level field studies have examined nocturnal isoprene oxidation in both polluted and remote forested environments. Although nighttime decays of surface-level isoprene are well-documented (Hurst et al., 2001; Trainer et al., 1991), their interpretation is often complicated by the competing effects of chemistry and transport, particularly within shallow nocturnal boundary layers (Apel et al., 2002). For example, measurements at forested sites impacted by urban $\mathrm{NO}_{\mathrm{x}}$ emissions have in several instances found evening isoprene loss rates consistent with consumption by $\mathrm{NO}_{3}$ radicals (Starn et al., 1998; Steinbacher et al., 2005; Stroud et al., 2002), while analysis of data from more remote locations have shown the importance of either transport or, possibly, additional oxidants such as nighttime $\mathrm{OH}$ (Biesenthal et al., 1998; Sillman et al., 2002). Analyses of surface level $\mathrm{NO}_{3}$ measurements in regions downwind of forested areas have shown that biogenic VOCs, including isoprene and monoterpenes, consume a significant fraction of $\mathrm{NO}_{3}$ radicals (Aldener et al., 2006; Ambrose et al., 2007; Geyer et al., 2001; McLaren et al., 2004). A ship-based study in coastal New England also found that reaction with $\mathrm{NO}_{3}$ was responsible for some $40 \%$ of the loss of isoprene advected over water from mixed urban/forested areas (Warneke et al., 2004).

Here, we report nocturnal observations of isoprene, its oxidation products and its major nighttime oxidants from the NOAA P-3 aircraft. This study differs from surface level measurements at a fixed location in that it provides a regional analysis of the degree to which isoprene is oxidized at night. Furthermore, the nighttime aircraft observations sample primarily above the nocturnal boundary layer and are therefore decoupled from surface emissions, nocturnal boundary layer dynamics and deposition. This study examines the fate of isoprene that is transported or oxidized aloft within the residual, daytime boundary layer, where the majority of the daytime-emitted isoprene remaining at sunset resides. Figure 1 shows the nighttime flight tracks of the P-3 superimposed on an isoprene emissions inventory map for this region (Guenther et al., 2006). These nighttime flights sampled in urban and forested regions across the Northeast US, an area with both large isoprene and $\mathrm{NO}_{\mathrm{x}}$ emissions, where $\mathrm{NO}_{3}-$ driven isoprene oxidation is likely to be particularly important.

\section{Experimental methods}

These measurements were part of the 2004 New England Air Quality Study (NEAQS), part of the larger Intercontinental Consortium for Atmospheric Research on Transport and Transformation (ICARTT) (Fehsenfeld et al., 2006), which took place in July and August in the Northeast US. Table 1 lists the trace gas and aerosol measurements relevant for this 
Table 1. Instruments used for analysis of nocturnal isoprene oxidation.

\begin{tabular}{lccl}
\hline Measurement/Technique & Accuracy & Frequency & Reference \\
\hline $\mathrm{NO}_{3}, \mathrm{~N}_{2} \mathrm{O}_{5} / \mathrm{CRDS}^{\mathrm{a}}$ & $25 \%$ & $1 \mathrm{~Hz}$ & (Dubé et al., 2006) \\
$\mathrm{NO}^{\mathrm{NO}} \mathrm{O}_{2}, \mathrm{O}_{3} / \mathrm{Chemiluminescence}^{\mathrm{b}}$ & $3-8 \%$ & $1 \mathrm{~Hz}$ & (Ryerson et al., 1999, 2000) \\
Rapid VOC/PTRMS $^{\mathrm{V}}$ & $10-20 \%$ & $0.08 \mathrm{~Hz}$ & (de Gouw et al., 2003) \\
Speciated VOC/Can Samples $^{\mathrm{c}}$ & $5-10 \%$ & $80 / f l i g h t$ & (Schauffler et al., 1999) \\
$\mathrm{HNO}_{3} / \mathrm{CIMS}^{\mathrm{d}}$ & $15 \%$ & $1 \mathrm{~Hz}$ & (Neuman et al., 2002) \\
Speciated PANs/CIMS $^{\mathrm{d}}$ & $20 \%$ & $0.5 \mathrm{~Hz}$ & (Slusher et al., 2004) \\
Aerosol composition/PiLS & $15 \%$ & $0.4 \mathrm{~min}^{-1}$ & (Weber et al., 2001) \\
WSOC/PiLS & $15 \%$ & $1 \mathrm{~min}^{-1}$ & (Weber et al., 2001) \\
\hline
\end{tabular}

${ }^{a}$ Cavity ring down spectroscopy, ${ }^{b}$ Proton transfer reaction mass spectrometry, ${ }^{\mathrm{c}}$ Analyzed by GC-MS, ${ }^{\mathrm{d}}$ Chemical ionization mass spectrometry, ${ }^{\mathrm{e}}$ Particle into liquid sampler.

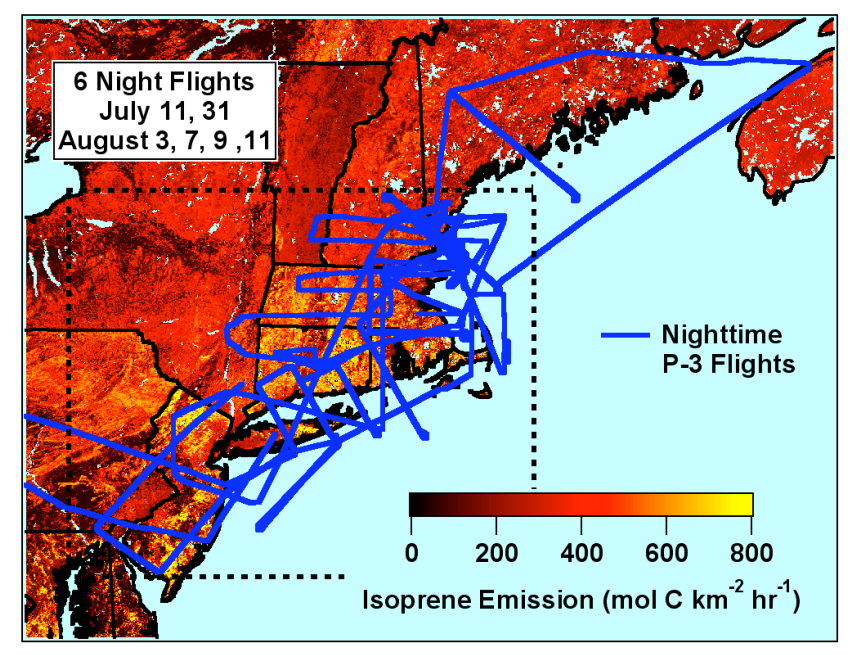

Fig. 1. Map of the Northeast US showing the MEGAN (Guenther et al. 2006) database for isoprene emissions and the nighttime P-3 flight tracks during the NEAQS 2004 campaign. The dashed box indicates the domain for the model calculation described in Sect. 5.

analysis. The instrument for measurement of $\mathrm{NO}_{3}$ and $\mathrm{N}_{2} \mathrm{O}_{5}$ was a two channel cavity ring-down spectrometer that detects $\mathrm{NO}_{3}$ by $662 \mathrm{~nm}$ optical extinction in an ambient temperature channel and the sum of $\mathrm{NO}_{3}$ and $\mathrm{N}_{2} \mathrm{O}_{5}$ in a second $662 \mathrm{~nm}$ channel with a heated inlet to convert $\mathrm{N}_{2} \mathrm{O}_{5}$ to $\mathrm{NO}_{3}$ (Dubé et al., 2006). The most important limitation to the measurement accuracy was the inlet transmisison efficiency, which during this campaign was calibrated before and after the field measurements in a series of laboratory experiments. More recent deployments of this insturment have included in-field calibrations, as described by Fuch et al. (2008). There were two separate VOC instruments: a proton transfer reaction mass spectrometer (PTRMS) for high time resolution measurements; and cannister samples for more speciated VOC measurements at higher precision but lower time resolution. The latter were collected in flight and analyzed post-flight by gas chromatography/mass spectrometery. Both instruments measured isoprene and its oxidation products, methyl vinyl ketone (MVK) and methacrolein (MACR). The two instruments agreed to within experimental uncertainties (de Gouw and Warneke, 2007). For isoprene measurements, the PTRMS is less specific and may show interferences at low levels (see below). The PTRMS also measures MVK and MACR as the sum of the two compounds, whereas the cannister samples speciate the two.

\section{$3 \mathrm{NO}_{\mathrm{x}}$ enhancement of nocturnal alkene ozonolysis}

Ozone and $\mathrm{NO}_{3}$ are both highly reactive toward unsaturated VOCs and are the most important nocturnal oxidants for isoprene. While ozone is more uniformly distributed in the troposphere and is thought to be a more important oxidant for isoprene globally, reaction with $\mathrm{NO}_{3}$ can easily dominate the nighttime chemical loss for isoprene on a regional scale. Because $\mathrm{NO}_{3}$ also requires ozone for its production, its further reaction with isoprene is equivalent to an enhancement to the background rate of nocturnal isoprene ozonolysis.

$\mathrm{O}_{3}+$ Isoprene $\rightarrow$ Products

$\mathrm{NO}_{2}+\mathrm{O}_{3} \rightarrow \mathrm{NO}_{3}+\mathrm{O}_{2}$

$\mathrm{NO}_{3}+$ Isoprene $\rightarrow$ Products

$-\frac{d[\text { Isop }]}{d t}=\left(k_{1}\left[\mathrm{O}_{3}\right]+k_{3}\left[\mathrm{NO}_{3}\right]\right)[$ Isop $]$

Quantities in square brackets indicate concentrations in number density units. In the early evening, when isoprene concentrations over a forested areas are large, isoprene will be the dominant reaction partner for $\mathrm{NO}_{3}$ radicals produced in reaction ( $\mathrm{R} 2$ ). Under these conditions, $\mathrm{NO}_{3}$ will rapidly achieve a steady state between reactions (R2) and (R3) such that its concentration can be approximately written as the ratio of its production rate and first-order loss rate coefficient (Platt et al., 1984). 

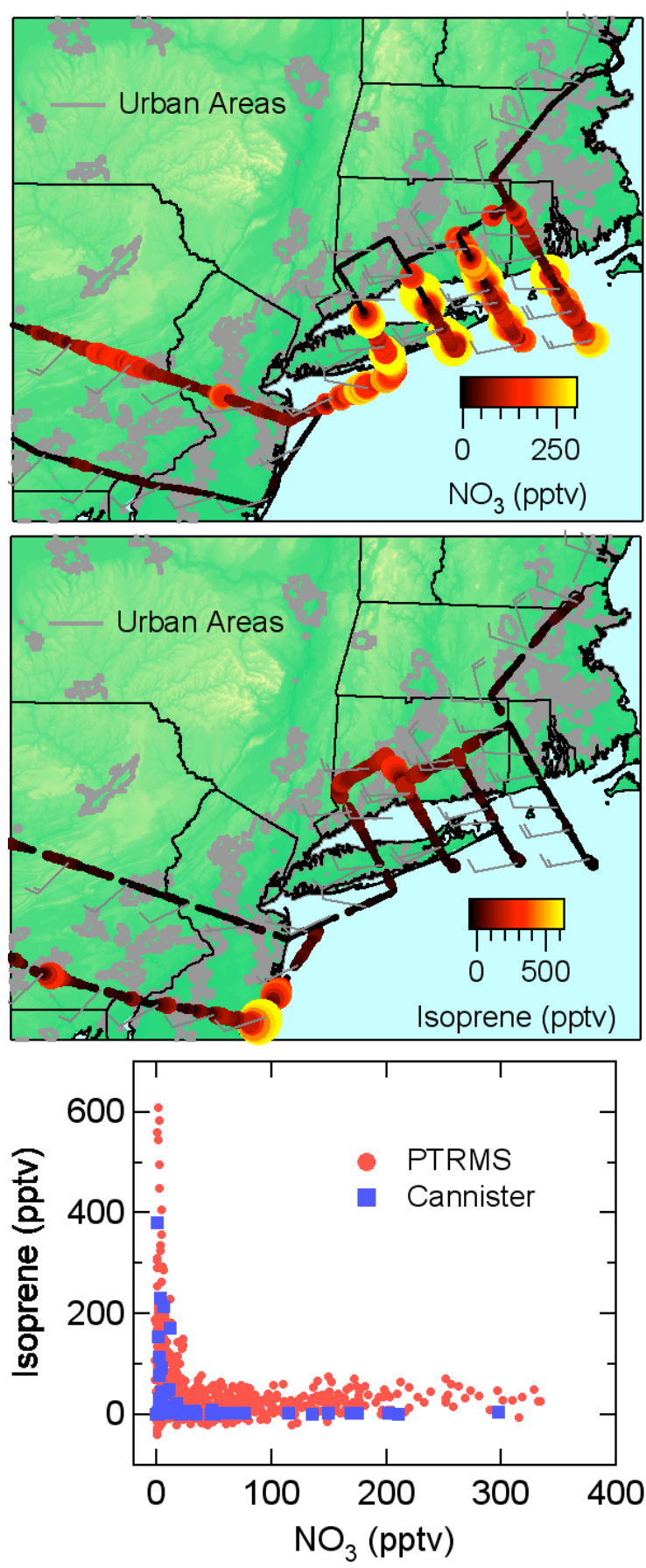

Fig. 2. Eastern part of the 9-10 August flight after sunset color and size code by $\mathrm{NO}_{3}$ (upper panel) and isoprene (middle panel, PTRMS data) mixing ratios. The altitude range for the majority of the flight track shown was 470-950 m. The lower panel shows the correlation plot between measured isoprene and $\mathrm{NO}_{3}$. Red points are PTRMS isoprene (high time resolution), and blue points are canister samples (low time resolution, higher precision). In some cases, there is a small background at the mass used for isoprene detection in the PTRMS $(\mathrm{m} / \mathrm{z}=69)$, evident on the comparison to the canister samples at high $\mathrm{NO}_{3}$.
$\left[\mathrm{NO}_{3}\right] \approx \Phi_{\text {Isop }} \frac{k_{2}\left[\mathrm{O}_{3}\right]\left[\mathrm{NO}_{2}\right]}{k_{3}[\mathrm{Isop}]}$

Here $\Phi_{\text {Isop }}$ is the fraction of $\mathrm{NO}_{3}$ radicals produced in reaction (R2) that react with isoprene (i.e., the ratio of the first order loss rate coefficient of $\mathrm{NO}_{3}$ with isoprene to the sum of all first order loss rate coefficients of $\mathrm{NO}_{3}$ radicals, including indirect loss by hydrolysis of $\mathrm{N}_{2} \mathrm{O}_{5}$ ). Substitution of Eq. (2) into Eq. (1) yields a simple result that demonstrates the enhancement of the background isoprene ozonolysis rate in the presence of $\mathrm{NO}_{\mathrm{x}}$.

$-\frac{d[\text { Isop }]}{d t} \approx\left(k_{1}[\right.$ Isop $\left.]+\Phi_{\text {Isop }} k_{2}\left[\mathrm{NO}_{2}\right]\right)\left[\mathrm{O}_{3}\right]$

In order for the $\mathrm{NO}_{3}$ reaction to consume a large fraction of the available isoprene, the concentration of $\mathrm{NO}_{2}$ must exceed that of isoprene such that $\mathrm{NO}_{\mathrm{x}}$ is not the limiting reagent. For $\left[\mathrm{NO}_{2}\right] \geq$ [Isop], the second term in Eq. (3) exceeds the first by at least a factor of 2.8 at $298 \mathrm{~K}$ (for $\Phi_{\text {Isop }} \approx 1$ ) (Atkinson and Arey, 2003), such that the $\mathrm{NO}_{3}$ reaction always dominates if there is sufficient $\mathrm{NO}_{2}$ available (e.g., Sommariva et al., 2008).

Figure 2 shows the eastern part of the P-3 track after sunset on the night of 9-10 August 2004, color and size coded by the mixing ratios of both $\mathrm{NO}_{3}$ and isoprene. (The western side of the track over western Pennsylvania and Ohio was characterized by lower isoprene and large sulfate aerosol loading, such that reactivity of $\mathrm{NO}_{3}$ and $\mathrm{N}_{2} \mathrm{O}_{5}$ was dominated by $\mathrm{N}_{2} \mathrm{O}_{5}$ uptake to particles rather than by $\mathrm{NO}_{3}$ isoprene chemistry, Brown et al., 2006b). Comparison of the two maps shows that the spatial distribution of $\mathrm{NO}_{3}$ and isoprene over the Northeast US were strongly anticorrelated, with $\mathrm{NO}_{3}$ present at large mixing ratios (up to $350 \mathrm{pptv}$ ) downwind of major urban areas, and isoprene present in all areas not impacted by rapid production of $\mathrm{NO}_{3}$. The scatter plot in the lower panel of Fig. 2 shows this anticorrelation, which was a persistent feature of all night flights in which measurable isoprene was present. As the next section demonstrates, the anticorrelation is not simply the result of the spatial distribution of isoprene and $\mathrm{NO}_{\mathrm{x}}$ emissions, but rather due to oxidation of a diffusely distributed background of isoprene in areas where the $\mathrm{NO}_{\mathrm{x}}$ levels were sufficient to rapidly consume isoprene in the hours just after sunset.

Figure 3 shows the time series of isoprene and the firstorder loss rate coefficients for $\mathrm{NO}_{3}$ radicals for the portion of the flight tracks shown in Fig. 2. The figure compares two different calculations of this rate coefficient. The first is the ratio of the production rate for $\mathrm{NO}_{3}$ from reaction (R2) to the observed $\mathrm{NO}_{3}$ concentration.

$\tau\left(\mathrm{NO}_{3}\right)^{-1}=\frac{k_{2}\left[\mathrm{O}_{3}\right]\left[\mathrm{NO}_{2}\right]}{\left[\mathrm{NO}_{3}\right]}$ 


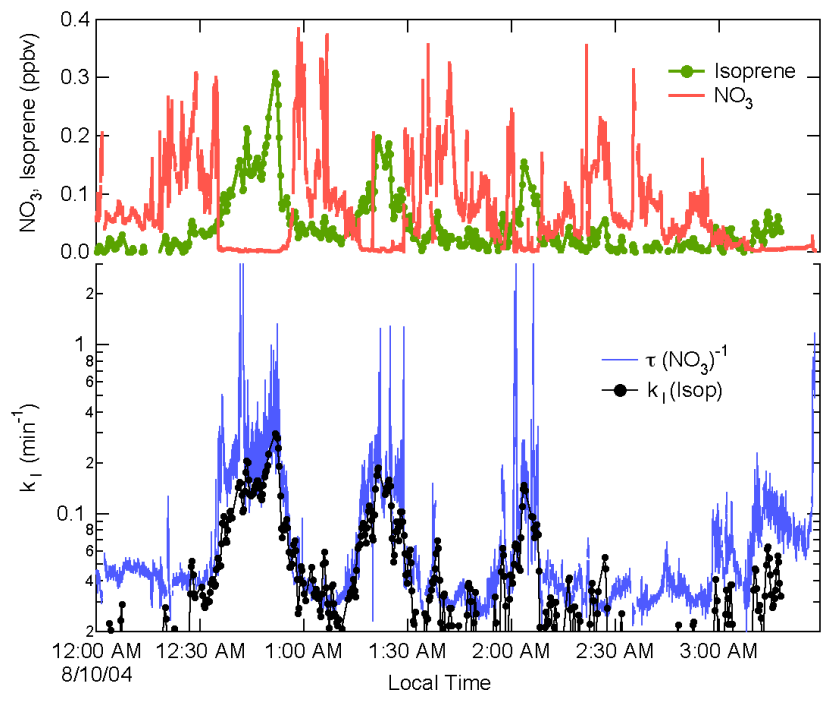

Fig. 3. Time series of isoprene and $\mathrm{NO}_{3}$ (top traces) and first-order loss rate coefficient for $\mathrm{NO}_{3}$ radicals (bottom traces) for the eastern part of the 9-10 August P-3 flight shown in Fig. 2. $\tau\left(\mathrm{NO}_{3}\right)^{-1}$ is the inverse steady state lifetime, or loss frequency, calculated according to equation (4), and $k_{I}$ (Isop) is the first-order loss rate coefficient for $\mathrm{NO}_{3}$ with measured isoprene from the PTRMS instrument according to Eq. (6).

This quantity, referred to as the inverse steady state lifetime (Platt et al., 1984) or the loss frequency (Geyer and Platt, 2002) for $\mathrm{NO}_{3}$, is a measure of the total first-order loss rate coefficient for $\mathrm{NO}_{3}$ radicals under conditions where the $\mathrm{NO}_{3}$ and $\mathrm{N}_{2} \mathrm{O}_{5}$ system has achieved a steady state with respect to production from reaction (R2) and losses to reactions of both $\mathrm{NO}_{3}$ and $\mathrm{N}_{2} \mathrm{O}_{5}$ (generally valid for conditions of rapid sinks for $\mathrm{NO}_{3}$ and $\mathrm{N}_{2} \mathrm{O}_{5}$, warmer temperatures, and lower $\mathrm{NO}_{2}$ concentrations, Allan et al., 2000; Brown et al., 2003). At steady state, the following approximate relationship between equation (4) and $\mathrm{NO}_{3}$ sinks holds.

$\tau\left(\mathrm{NO}_{3}\right)^{-1} \approx \sum_{i} k_{i}\left[\mathrm{VOC}_{i}\right]+K_{e q}\left[\mathrm{NO}_{2}\right] k_{\text {hydrolysis }}$

The first term on the right hand side above is a summation of the products of bimolecular rate coefficients and VOC concentrations for all VOCs that are reactive with $\mathrm{NO}_{3}$. The second term is the indirect loss rate coefficient for $\mathrm{NO}_{3}$ radicals due to hydrolysis of $\mathrm{N}_{2} \mathrm{O}_{5}$, with a first-order uptake coefficient to aerosols $k_{\text {hydrolysis. }}$. $\mathrm{K}_{e q}$ is the temperature dependent equilibrium constant for the reversible reaction of $\mathrm{NO}_{3}$ with $\mathrm{NO}_{2}$ to form $\mathrm{N}_{2} \mathrm{O}_{5}$. This expression neglects daytime reactions, such as photolysis of $\mathrm{NO}_{3}$ and reaction of $\mathrm{NO}_{3}$ with $\mathrm{NO}$, and heterogeneous uptake of $\mathrm{NO}_{3}$ (although the latter could easily be incorporated into the summation).

The second calculation of the $\mathrm{NO}_{3}$ first order loss rate coefficient in Fig. 3 is the loss of $\mathrm{NO}_{3}$ due only to reaction with isoprene.

$k_{I}($ Isoprene $)=k_{3}[$ Isop $]$

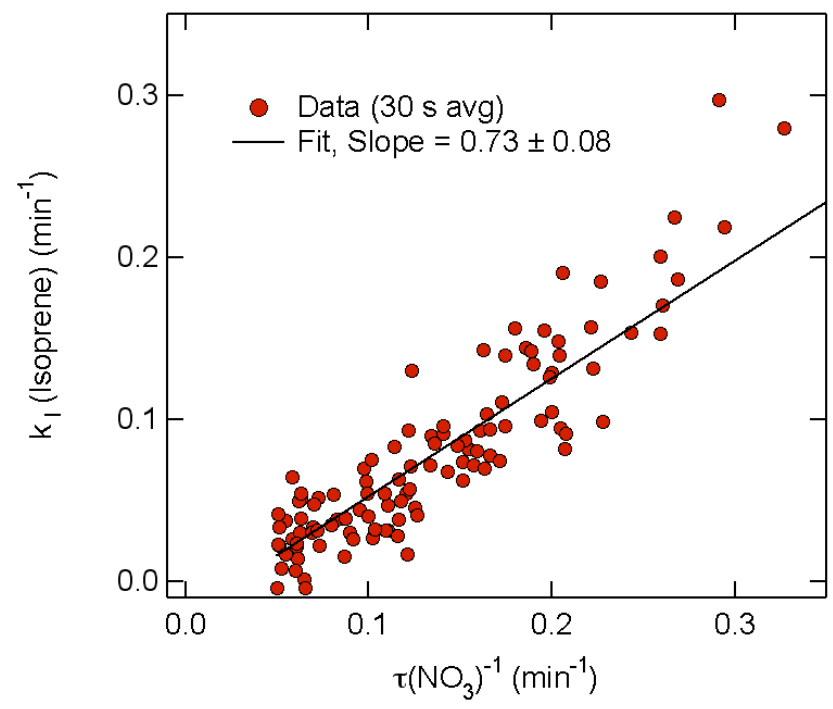

Fig. 4. Plot of first-order loss rate coefficient for $\mathrm{NO}_{3}$ with isoprene against inverse $\mathrm{NO}_{3}$ lifetime for the data in Fig. 3, averaged to $30 \mathrm{~s}$ and for inverse $\mathrm{NO}_{3}$ lifetimes $>0.05 \mathrm{~min}^{-1}$ ( $\approx 50 \mathrm{pptv}$ isoprene), above which isoprene loss is the controlling factor.

Here, $k_{3}$ is the bimolecular rate coefficient for reaction (R3). Although Eq. (6) represents only a single term from the summation in Eq. (5), the correspondence of the time series between the two independently measured quantities in Fig. 3 is remarkable. The plot of $\tau\left(\mathrm{NO}_{3}\right)^{-1}$ vs. $k_{I}$ (Isoprene) in Fig. 4 shows that for isoprene levels greater than $50 \mathrm{pptv}$, loss to isoprene accounted for $73 \pm 8 \%$ of the $\mathrm{NO}_{3}$ loss determined from $\tau\left(\mathrm{NO}_{3}\right)^{-1}$. This observation suggests not only that the approximate isoprene loss rate in Eq. (3) is valid, but that the value of $\Phi_{\text {Isop }}$ can be taken as $\sim 0.73$. This value may be taken as an average above $50 \mathrm{pptv}$ isoprene, since at very large isoprene, the value of $\Phi_{\text {Isop }}$ should approach unity (see upward curvature in Fig. 4). The remaining consumption of $\mathrm{NO}_{3}$ radicals is not defined here, although possibilities include reactions with other biogenic VOC, second generation isoprene oxidation products, peroxy radicals and heterogeneous uptake of either $\mathrm{NO}_{3}$ or $\mathrm{N}_{2} \mathrm{O}_{5}$ (although the latter was negligible for the eastern leg of the 9-10 August flight, Brown et al., 2006b).

This analysis shows that isoprene, when present within the residual daytime boundary layer (observed here to be approximately $0.1-1.5 \mathrm{~km}$, Brown et al., 2007), controls the loss of $\mathrm{NO}_{3}$ and therefore the consumption of $\mathrm{NO}_{\mathrm{x}}$ at night. Furthermore, under the assumption that nighttime $\mathrm{OH}$ contributes negligibly to isoprene oxidation, a large fraction of the isoprene present at sunset within $\mathrm{NO}_{\mathrm{x}}-$ containing air masses is lost to reaction with $\mathrm{NO}_{3}$ rather than reacting with ozone or being transported overnight. The next section outlines a method by which isoprene and $\mathrm{NO}_{2}$ at sunset may be estimated for nocturnally sampled air masses. Sunset $\mathrm{NO}_{2}$ was nearly always in excess over isoprene, such that the second 
term in Eq. (3) was dominant. In fact, comparison of the two terms in Eq. (3) at sunset shows that well over $90 \%$ of the isoprene oxidized in the dark was lost to reaction with $\mathrm{NO}_{3}$ rather than ozone. Thus, in an area with large regional $\mathrm{NO}_{\mathrm{x}}$ and isoprene emissions such at the Northeast US, $\mathrm{NO}_{\mathrm{x}}$ emissions are a determining factor for isoprene loss budgets overnight.

\section{Relationship between isoprene and MVK+MACR at night}

The products of the photochemical oxidation of isoprene, methyl vinyl ketone and methacrolein (MVK+MACR), serve as tracers for the presence of isoprene chemistry within the residual daytime boundary layer at sunset. These compounds are produced in high yields from the atmospheric oxidation of isoprene by either $\mathrm{OH}$ or $\mathrm{O}_{3}$ (Atkinson and Arey, 2003) but at low yields (3.5\%) in the $\mathrm{NO}_{3}$ oxidation of isoprene (Kwok et al., 1996). Nighttime oxidation of isoprene by ozone produces MVK+MACR, but much more slowly than does $\mathrm{OH}$ oxidation, and their production is nearly negligible if most of the nighttime oxidation occurs via $\mathrm{NO}_{3}$. Furthermore, these compounds are much less reactive with either $\mathrm{O}_{3}$ or $\mathrm{NO}_{3}$ than isoprene itself. Surface level measurements have shown that MVK+MACR change only slowly at night while isoprene decays rapidly in air masses with a large $\mathrm{NO}_{3}$ production rate (Stroud et al., 2002). Because methyl vinyl ketone and methacrolein have the same mass, they are measured as a single sum by the PTRMS instrument.

Figure 5 shows maps of the night flight on 3 August 2004, color and size coded by $\mathrm{NO}_{3}$, isoprene and MVK+MACR. The spatial distribution of isoprene and $\mathrm{NO}_{3}$ is similar to that for the 9-10 August flight shown in Fig. 2, and the scatter plot of isoprene against $\mathrm{NO}_{3}$ again shows the same anticorrelation observed between these compounds that was characteristic of the night flights. The spatial distribution of MVK+MACR is considerably different, however. This tracer is more uniformly distributed than isoprene and appears in areas where isoprene is absent but $\mathrm{NO}_{3}$ is present at large mixing ratios. The observed anticorrelation between $\mathrm{NO}_{3}$ and isoprene at night was therefore not simply a result of spatial separation between $\mathrm{NO}_{\mathrm{x}}$ and isoprene emissions, but rather due to oxidation of isoprene in regions where $\mathrm{NO}_{\mathrm{x}}$ emissions provided a sufficient $\mathrm{NO}_{3}$ source.

\section{Isoprene oxidized after dark}

The amount of isoprene that had been present at sunset in air masses sampled after dark may be calculated directly from integration of Eq. (3) backwards in time. The choice of sunset as a starting point is arbitrary in that the transition from daytime, photochemical oxidation to nighttime, $\mathrm{NO}_{3}$ oxidation does not occur suddenly, but gradually. However, the period around sunset is one in which previous studies have

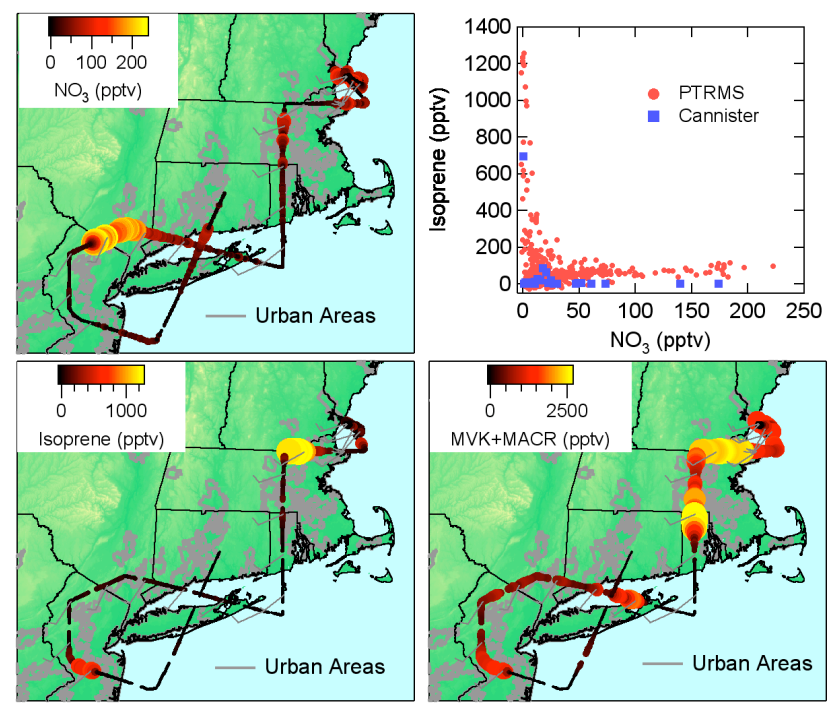

Fig. 5. Tracks for the 3 August 2004 night flight color and size coded by $\mathrm{NO}_{3}$ mixing ratio (upper left), isoprene (lower left) and methyl vinyl ketone+methacrolein (MVK+MACR) (lower right). The abrupt end to the flight track over Connecticut was due to a technical difficulty that forced the suspension of data collection at that point. The upper right graph shows the correlation plot between isoprene and $\mathrm{NO}_{3}$ as in Fig. 2.

shown at most very slow oxidative processes (e.g. Brown et al., 2004), such that this time can be taken as the transition point with minimal error. This analysis is only possible for air samples in which measurable isoprene remains in an air mass at night because the isoprene concentration itself appears in this equation and because the approximation relies on the assumption that isoprene is the major reaction partner for $\mathrm{NO}_{3}$. It further relies on the assumption that air masses sampled aloft at night were decoupled from surface emissions trapped within the shallow nocturnal boundary layer after sunset. The integral has an analytical solution under the assumption of constant ozone over the period since sunset; the validity of this approximation depends on the amount of ozone consumed in reaction (R2) and is appropriate for ozone in large excess over $\mathrm{NO}_{2}$, which was generally the case for the analysis presented here $\left(\mathrm{O}_{3} \sim 20-100 \times \mathrm{NO}_{2}\right)$. Because $\mathrm{N}_{2} \mathrm{O}_{5}$ hydrolysis is unimportant in comparison to the reaction of $\mathrm{NO}_{3}$ with isoprene for large isoprene levels, the rate of $\mathrm{NO}_{2}$ consumption, which is explicitly incorporated into the expression below, is equal to the rate of reaction (R2) (rather than being twice this rate, as would be the case if $\mathrm{N}_{2} \mathrm{O}_{5}$ hydrolysis were dominant, Brown et al., 2004). However, the $\mathrm{NO}_{3}$ +isoprene reaction regenerates a fraction of $\mathrm{NO}_{2}$ with a yield, $\Phi_{\mathrm{NO}_{2}}$, of $20 \%$; the remainder of the nitrogen goes to organic nitrates (Barnes et al., 1990). 


$$
\begin{aligned}
\mathrm{NO}_{3}+\text { Isoprene } & \rightarrow \text { OVOC }+\mathrm{NO}_{2} & \Phi_{\mathrm{NO}_{2}}=0.2 \\
& \rightarrow \mathrm{RONO}_{2} & \Phi_{\mathrm{RONO}_{2}}=0.8
\end{aligned}
$$

With these assumptions, the integral of Eq. (3) over the time interval to sunset (taken here as solar zenith angle of $90^{\circ}$ at the sampling location) has an analytical solution for the initial isoprene.

$$
\begin{aligned}
& {[\text { Isop }]_{0}=[\mathrm{Isop}] e^{k_{1}\left[\mathrm{O}_{3}\right] \Delta t}+} \\
& \frac{\Phi_{\mathrm{Isop}} k_{2}\left[\mathrm{NO}_{2}\right] e^{\Phi_{S} k_{2}\left[\mathrm{O}_{3}\right] \Delta t}}{\Phi_{S} k_{2}-k_{1}}\left(1-e^{\left(k_{1}-\Phi_{S} k_{2}\right)\left[\mathrm{O}_{3}\right] \Delta t}\right) \\
& \Phi_{S}=1-\Phi_{\mathrm{Isop}} \Phi_{\mathrm{NO}_{2}}
\end{aligned}
$$

Here $\Delta \mathrm{t}$ is the time since sunset, [Isop], $\left[\mathrm{NO}_{2}\right]$ and $\left[\mathrm{O}_{3}\right]$ are the observed isoprene, $\mathrm{NO}_{2}$ and $\mathrm{O}_{3}$ concentrations, $k_{1}$ and $k_{2}$ are the bimolecular rate coefficients for the reaction of $\mathrm{O}_{3}$ with isoprene and $\mathrm{NO}_{2}$, respectively, and $\Phi_{\text {Isop }}$ is the fraction of $\mathrm{NO}_{3}$ radicals produced in reaction (R2) that react with isoprene (taken as a constant $\Phi_{\text {Isop }}=0.73$, see above).

Figure 6 shows initial isoprene calculated from Eq. (7) for the 3 August flight as a time series along with observed isoprene and MVK+MACR. The lower panel of this figure gives the correlation between calculated initial isoprene and observed MVK+MACR. The correlation between derived sunset isoprene and observed MVK+MACR on the 3 August flight (correlation coefficient $=0.72$, see Table 2 ) was higher than for other flights. For this flight, MVK+MACR has been used to estimate sunset isoprene even in air masses where the isoprene had already been completely lost to oxidation. The slope of the correlation plot in Fig. 6 is $0.6 \pm 0.3$, where the $\pm 50 \%$ error bars, shown as dashed lines on the plot represent limits that encompass the majority of the data. The ratio of isoprene to MVK+MACR at sunset is expected to be variable since it depends on the time of emission and the photochemical processing time prior to sunset. Measured values of this ratio for late day measurements (within $3 \mathrm{~h}$ prior to $0.5 \mathrm{~h}$ after sunset) from NEAQS 2004 gave an average value of $0.4 \pm 0.3$ $( \pm 1 \sigma)$. Values from surface level measurements, on the other hand, tend to be somewhat larger, approximately 1:1 (e.g., Stroud et al., 2002). The correlation between derived sunset isoprene and MVK+MACR for the 3 August flight, and the large late-day isoprene emission on this flight (see below), indicate that the use of MVK+MACR as a semi-quantitative isoprene tracer is appropriate for this flight.

Figure 7 shows the estimate for isoprene oxidized after dark for the 3 August flight. As described above, this estimate is taken as a constant ratio of $0.6 \pm 0.3$ times the MVK+MACR data, minus the measured isoprene still present in the air mass. Maximum values for this estimate are in the range of 1-2 ppbv. Also shown is the integrated isoprene emission into each sampled air mass on the preceding day, calculated using a Lagrangian particle dispersion model (FLEXPART) (Stohl et al., 2005). FLEXPART was driven
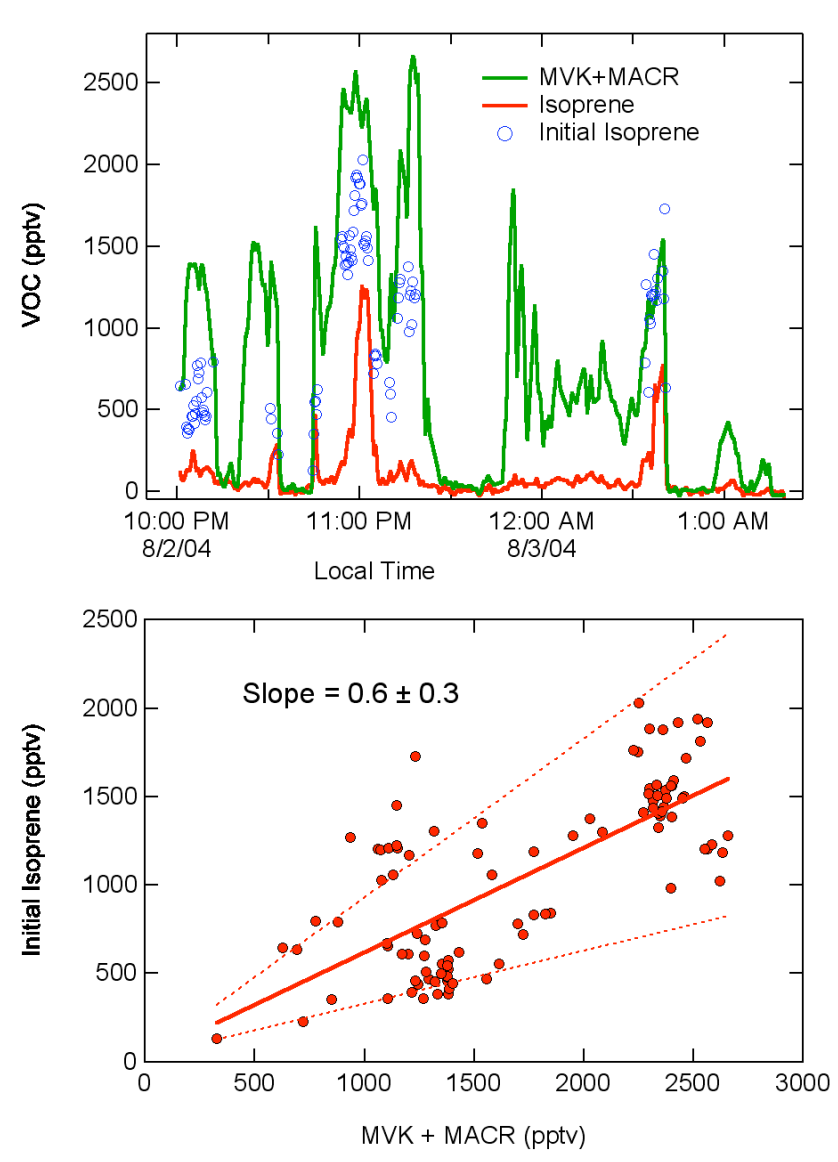

Fig. 6. Upper panel: Time series of isoprene, methyl vinyl ketone+methacrolein (MVK+MACR) and isoprene present at sunset calculated according to Eq. (7) for isoprene $>100$ pptv. Lower panel: Plot of initial isoprene vs. MVK+MACR with a linear fit with a slope of $0.6 \pm 0.3$ and a correlation coefficient of 0.72 . This correlation can be used to estimate sunset isoprene from the MVK+MACR data for the entire flight.

by model-level data from the European Centre for MediumRange Weather Forecasts (ECMWF) with a temporal resolution of $3 \mathrm{~h}$ (analyses at 00:00, 06:00, 12:00, 18:00 UTC; 3-h forecasts at 03:00, 09:00, 15:00, 21:00 UTC) and 91 vertical levels and a horizontal resolution of $0.360 \times 0.360$. Isoprene emissions were taken from BEIS3.12. The temperature and light dependence of isoprene was calculated hourly for each isoprene emission grid with the EPA recommended canopy environment model by using the ECMWF $2 \mathrm{~m}$ temperature and net solar radiation, interpolated linearly in space and time using the two nearest ECMWF fields.

One calculation shows isoprene emissions for the preceding daylight hours, and a second shows emissions for only the $6 \mathrm{~h}$ preceding the time of sampling. These late day emissions were calculated to sometimes be a large fraction of the total, reflecting the air mass history. In the early part of the flight, backward trajectories had passed over the isoprenerich areas of western Massachusetts, as illustrated in the map 
Table 2. Night flights during NEAQS 2004 and ratio of sunset isoprene, determined from Eq. (7), to observed MVK+MACR.

\begin{tabular}{clccc}
\hline Date \& Time & Location & Sunset Isop/MVK+MACR & Range & Correlation Coef. $(r)$ \\
\hline 11 July 18:55-23:51 EDT & Boston & 0.4 & $0.2-0.7$ & 0.65 \\
31 July 17:24-1 Aug 01:16 & CT, RI, MA & 0.6 & $0.2-1.2$ & 0.28 \\
2 Aug 21:53-3 Aug 04:23 & NH, MA, RI, NYC & 0.6 & $0.3-0.9$ & 0.72 \\
7 Aug 16:08-8 Aug 00:35 & Coastal Areas Offshore flow & 0.8 & $0.2-1.2$ & 0.57 \\
9 Aug 18:57-10 Aug 03:29 & Northeast US-Ohio & 0.6 & $0.2-1.2$ & 0.54 \\
10 Aug 23:00-11 Aug 06:51 & Maine, Atlantic Ocean & N/A $^{\text {a }}$ & & \\
\hline
\end{tabular}

a No determination from this flight.
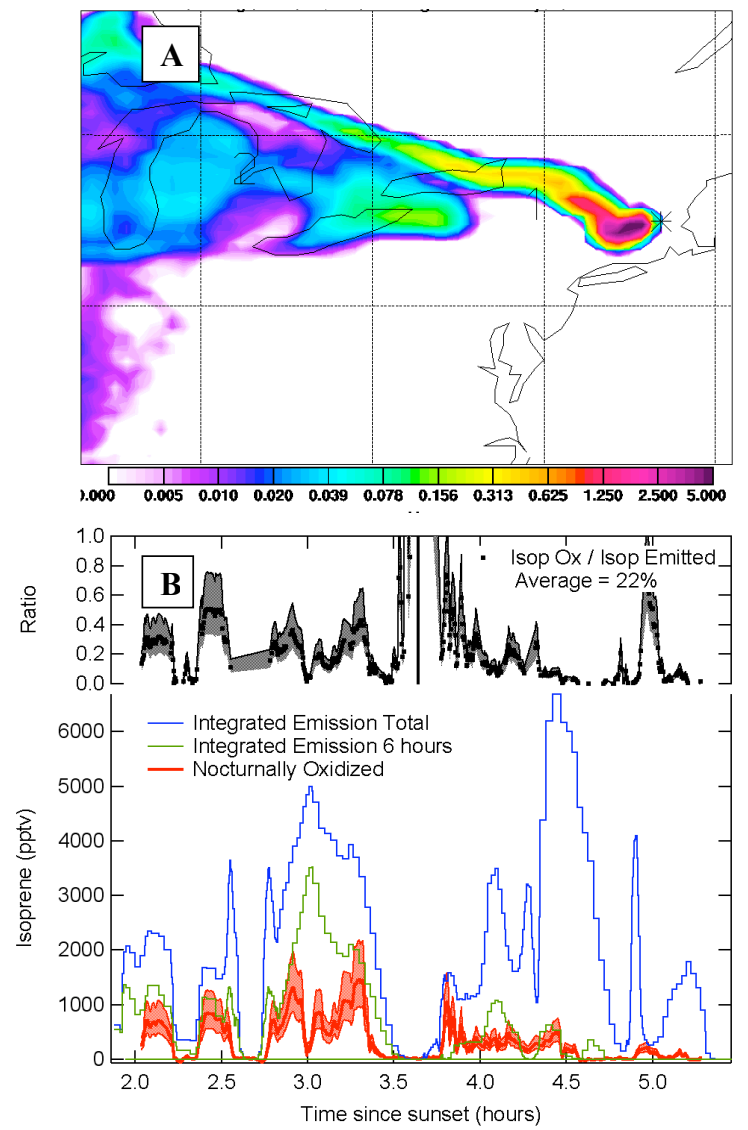

Fig. 7. (A) Sample FLEXPART footprint for one point on the P-3 flight track (asterisk). The plot shows residence time (per unit mass of a uniformly distributed, arbitrary tracer emission) of the air mass in the boundary layer on a logarithmic color scale. (B) Time series of the determined isoprene oxidized in the dark and the integrated isoprene emissions from the preceding day from the FLEXPART model for the 3 August flight. The trace over the top shows the ratio of the determination of isoprene oxidized after dark to integrated FLEXPART isoprene emissions.

in the lower panel of the figure. For air masses sampled below the top of the residual daytime boundary layer on this flight $(<1.5 \mathrm{~km})$, the average ratio of the isoprene oxidized after dark to the total emissions was $22 \pm 11 \%$, although values over Massachusetts were larger. The estimated isoprene oxidized after dark was a large fraction of the isoprene emitted within the preceding $6 \mathrm{~h}$ of the sample time in the early part of the flight. The flight began approximately two hours after local sunset, so that in the early part of the flight, the calculated $6 \mathrm{~h}$ isoprene emissions, which are sunlight dependent, would have occurred within 2-4 h of sunset.

The fraction of isoprene oxidized after dark determined from the 3 August flight can be compared to models of North American isoprene oxidation. For example, a recent calculation of the fraction of total North American isoprene emissions that are oxidized by $\mathrm{NO}_{3}$ puts this figure at $6 \%$ (Horowitz et al., 2007). Within a domain that includes only the Northeast US, encompassing the land areas sampled by the flight tracks shown in Fig. 1, a WRF-CHEM (Weather Research Forecast) model simulation for a single summer day predicts $8 \%$ of total isoprene emissions oxidized by $\mathrm{NO}_{3}$ for clear sky conditions, and $20 \%$ for cloudy conditions. These WRF-CHEM runs use the same domain, photochemistry, updated 2004 anthropogenic emissions and physics options as those documented in (Kim et al., 2006), however they are based on a newer release of WRF and WRF-CHEM (ARW version 3.0, Skamarock et al., 2008). The value of $22 \pm 11 \%$ is larger than these domain-wide average estimates, likely because of sampling in an air mass with large late-day isoprene emissions in close proximity to $\mathrm{NO}_{\mathrm{x}}$ pollution sources. This relatively larger fraction of isoprene emissions that are oxidized by $\mathrm{NO}_{3}$ inferred from some of the NEAQS flights has consequences for ozone, reactive nitrogen and aerosol growth, as outlined in the next sections.

\section{Reactive nitrogen partitioning}

The products of the $\mathrm{NO}_{3}+$ isoprene reaction are primarily organic nitrates that may contribute measurably to total reactive nitrogen $\left(\mathrm{NO}_{\mathrm{y}}\right)$. Starn et al. (1998) estimated $\mathrm{NO}_{3}$ derived isoprene nitrates to be $8 \%$ of total reactive nitrogen at an $\mathrm{NO}_{\mathrm{x}}$ impacted forested site. Direct measurements of the organic nitrates from nocturnal isoprene oxidation, however, are sparse. Ballschmitter and coworkers measured these 


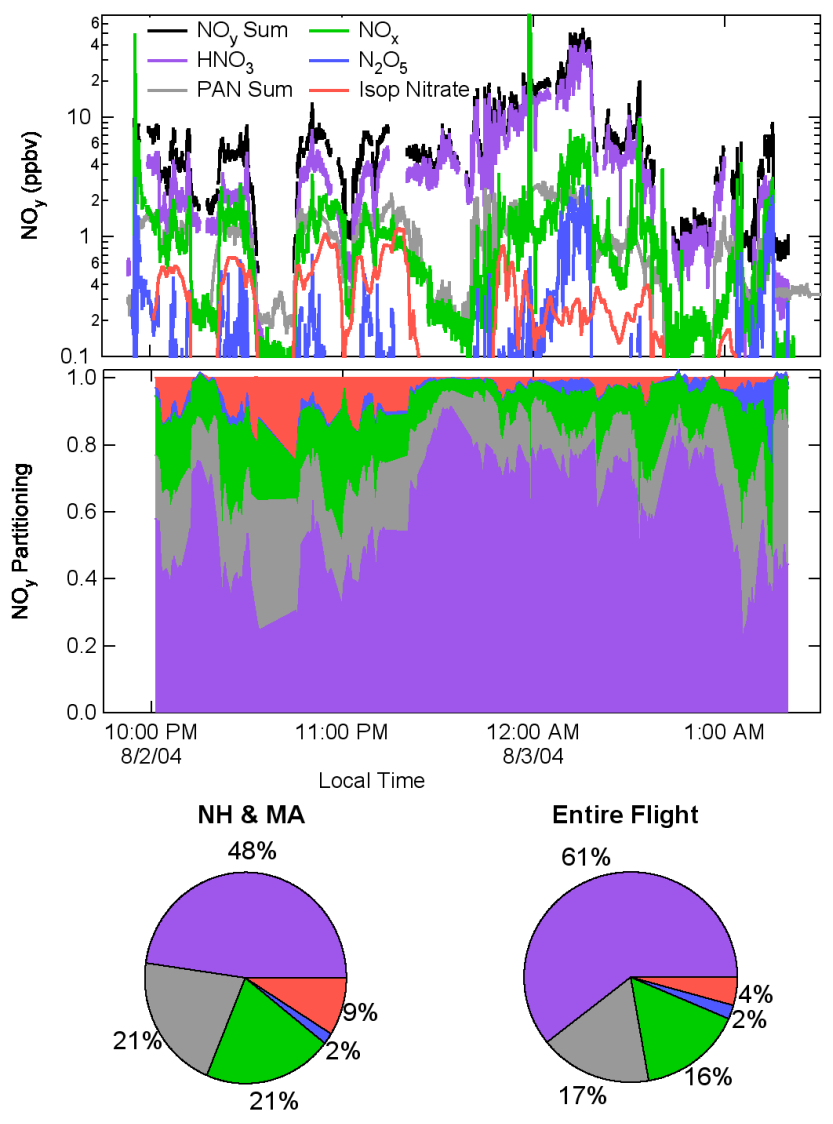

Fig. 8. Top: Time series of reactive nitrogen compounds for the 2-3 August flight according to the color scale on the legend. The large plume near midnight local time was from New York City, and the smaller plumes that preceded it were from the isoprene rich areas over New Hampshire, Massachusetts and Rhode Island. Center: Time series of reactive nitrogen partitioning according to the same color code. Bottom: Pie charts for average partitioning for the isoprene rich areas early in the flight (left) and for the entire flight (right). Uncertainties for fractions of reactive nitrogen due to isoprene nitrates are $\pm 50 \%$.

compounds by chromatographic methods in remote areas (e.g., marine environments) where there were only very small concentrations (Fischer et al., 2000; Werner et al., 1999). Shepson and coworkers reported diurnal patterns for these compounds in forested regions in Michigan and Tennessee (Giacopelli et al., 2005; Grossenbacher et al., 2001, 2004) but focused mainly on the photochemical production from reactions of isoprene peroxy radicals with NO. For the P-3 flights during NEAQS 2004, there were no specific measurements of isoprene nitrates.

Figure 8 shows a time series of different components of reactive nitrogen, including $\mathrm{HNO}_{3}$, PAN (shown here as the sum of speciated PANs measured with a chemical ionization mass spectrometer, see Table 1), $\mathrm{NO}_{\mathrm{x}}, \mathrm{N}_{2} \mathrm{O}_{5}$ and isoprene nitrates from isoprene $+\mathrm{NO}_{3}$. The isoprene nitrate trace is the product of the estimate for total isoprene reacted after dark and the laboratory organic nitrate yield of $80 \%$ (Barnes et al., 1990) and includes only production of these nitrates. Potential loss of these nitrates due to further reaction with $\mathrm{NO}_{3}$ or with $\mathrm{O}_{3}$ could reduce the amount of reactive nitrogen stored in this form if it were to result in release of $\mathrm{NO}_{2}$ from the nitrate, or increase the amount of organic nitrate if, for example, further reaction with $\mathrm{NO}_{3}$ were to result in the production of di-nitrates. The calculation does not include an estimate for isoprene nitrates derived from the photochemical reactions of isoprene peroxy radicals with $\mathrm{NO}$, which are thought to be between approximately $4-10 \%$ of the isoprene oxidized during daytime under high $\mathrm{NO}_{\mathrm{x}}$ conditions (Chen et al., 1998; Sprengnether et al., 2002). Although regional models predict approximately equal production of isoprene nitrates from daytime and nighttime mechanisms (Horowitz et al., 2007), for the air masses sampled on the 3 August flight, where a large fraction of the emitted isoprene were shown to have been oxidized after dark, isoprene nitrates derived from $\mathrm{NO}_{3}$ should dominate over their photochemical analogs. Also shown in Fig. 8 is the sum of reactive nitrogen, denoted here as $\mathrm{NO}_{\mathrm{y}}$ Sum. This sum is not a direct measurement from an $\mathrm{NO}_{\mathrm{y}}$ instrument (not available for these flights) but from the sum of all of the compounds shown in the time series, including $2 \times \mathrm{N}_{2} \mathrm{O}_{5}$. The middle panel of Fig. 8 shows the partitioning among these compounds, and the two pie charts at the bottom show the average partitioning for the early part of the flight, over the isoprene rich areas of New Hampshire, Massachusetts and Rhode Island, and for the entire flight.

Nitric acid was the dominant component of reactive nitrogen on this and other night flights during this campaign. Because the aircraft samples from the residual daytime boundary layer, which decouples from the surface at night, soluble gases such as $\mathrm{HNO}_{3}$ do not undergo efficient loss to dry deposition, and are longer-lived than on daytime flights in well mixed boundary layers (Neuman, 2006). Analysis of $\mathrm{HNO}_{3}$ $\mathrm{O}_{3}$ correlations (Brown et al., 2006a) and steady state lifetimes of $\mathrm{NO}_{3}$ and $\mathrm{N}_{2} \mathrm{O}_{5}$ (Brown et al., 2006b) (not shown) showed that much of the $\mathrm{HNO}_{3}$ in the early part of the flight had been formed photochemically from reaction of $\mathrm{NO}_{2}$ with $\mathrm{OH}$, while the plume over New York City sampled later in the flight had a large contribution from $\mathrm{N}_{2} \mathrm{O}_{5}$ hydrolysis. The dominance of $\mathrm{HNO}_{3}$ resulting from $\mathrm{N}_{2} \mathrm{O}_{5}$ hydrolysis within the New York City plume reduced the relative contribution of isoprene nitrates to $\mathrm{NO}_{\mathrm{y}}$, although the total mass of these compounds was still similar to the earlier part of the flight.

The calculated isoprene nitrates from nocturnal oxidation represent $9 \pm 5 \%$ and $4 \pm 2 \%$ of total reactive nitrogen in the isoprene-rich areas and in the New York plume, respectively. In the isoprene-rich areas, this contribution was slightly less than half of PAN, the longest-lived component of $\mathrm{NO}_{\mathrm{y}}$. As noted above, the fate of $\mathrm{NO}_{3}$-derived isoprene nitrates is highly uncertain, and they may be quite reactive. If, however, the $\mathrm{NO}_{3}$-derived isoprene nitrates were as long-lived as PAN compounds, they could represent a large fraction of 


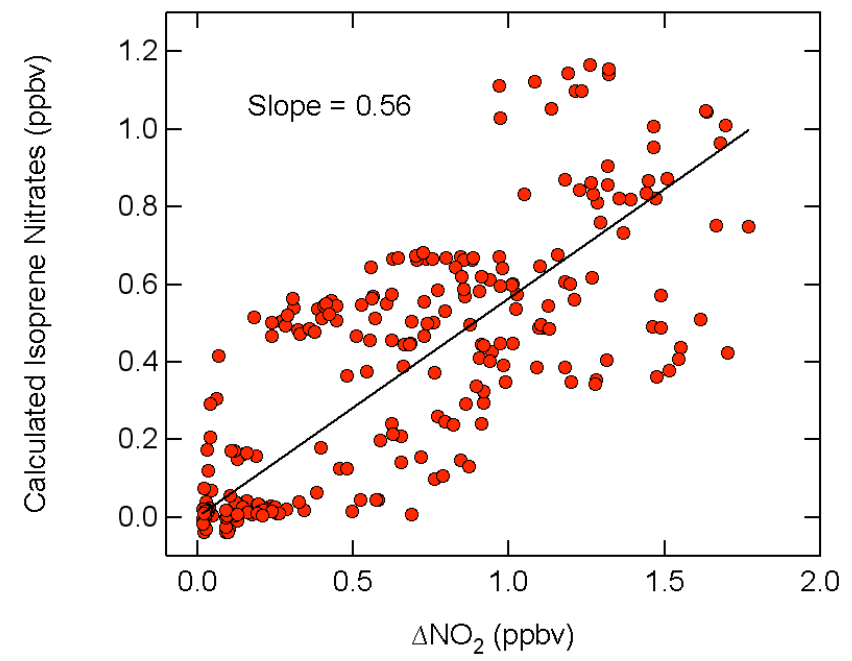

Fig. 9. Plot of calculated isoprene nitrates from $\mathrm{NO}_{3}+$ isoprene against the calculated $\mathrm{NO}_{2}$ that had been oxidized after sunset, assuming that reactions of $\mathrm{NO}_{3}$ were dominant compared to $\mathrm{N}_{2} \mathrm{O}_{5}$ hydrolysis, for the first half of the 3 August flight.

$\mathrm{NO}_{\mathrm{y}}$ as the air mass ages and as $\mathrm{NO}_{\mathrm{x}}$ and $\mathrm{HNO}_{3}$ are lost to oxidation and deposition.

The importance of isoprene nitrates to reactive nitrogen partitioning at night can be demonstrated by examining only the nighttime $\mathrm{NO}_{\mathrm{x}}$ oxidation products. Figure 9 is a plot of calculated isoprene nitrates against the calculated amount of $\mathrm{NO}_{2}$ oxidized after dark (i.e., $\Delta\left[\mathrm{NO}_{2}\right]=\left[\mathrm{NO}_{2}\right]\left(\exp \left(k_{1}\left[\mathrm{O}_{3}\right] \Delta \mathrm{t}_{\text {sunset }}-1\right)\right)$. The slope is 0.56 , indicating that about half of the $\mathrm{NO}_{2}$ consumed in darkness led to production of isoprene nitrates. Although the production of $\mathrm{NO}_{3}$-derived isoprene nitrates generally amounted to less than $10 \%$ of total $\mathrm{NO}_{\mathrm{y}}$, they were approximately half of the $\mathrm{NO}_{\mathrm{x}}$ consumption after dark in this air mass. Similar analyses hold for the other night flights analyzed for this campaign, as shown in Table 3. These observations are in part a consequence of measurements from aircraft in the residual daytime boundary layer, which are isolated from $\mathrm{NO}_{\mathrm{x}}$ emissions occurring below the nocturnal boundary layer and are thus likely to show evidence for a larger fraction of photochemical $\mathrm{NO}_{\mathrm{y}}$ oxidation products, such as PAN and photochemically generated $\mathrm{HNO}_{3}$. At lower altitudes, particularly the upper portion of the nocturnal boundary layer, the oxidation products of the nighttime reactions may represent a larger fraction of $\mathrm{NO}_{\mathrm{y}}$ (Brown et al., 2007; Stutz et al., 2004).

\section{Secondary organic aerosol}

The production of secondary organic aerosol (SOA) is a topic of considerable current interest. For example, analyses of VOC and aerosol data in the same region of the Northeast US have shown that organic aerosol is well-correlated with
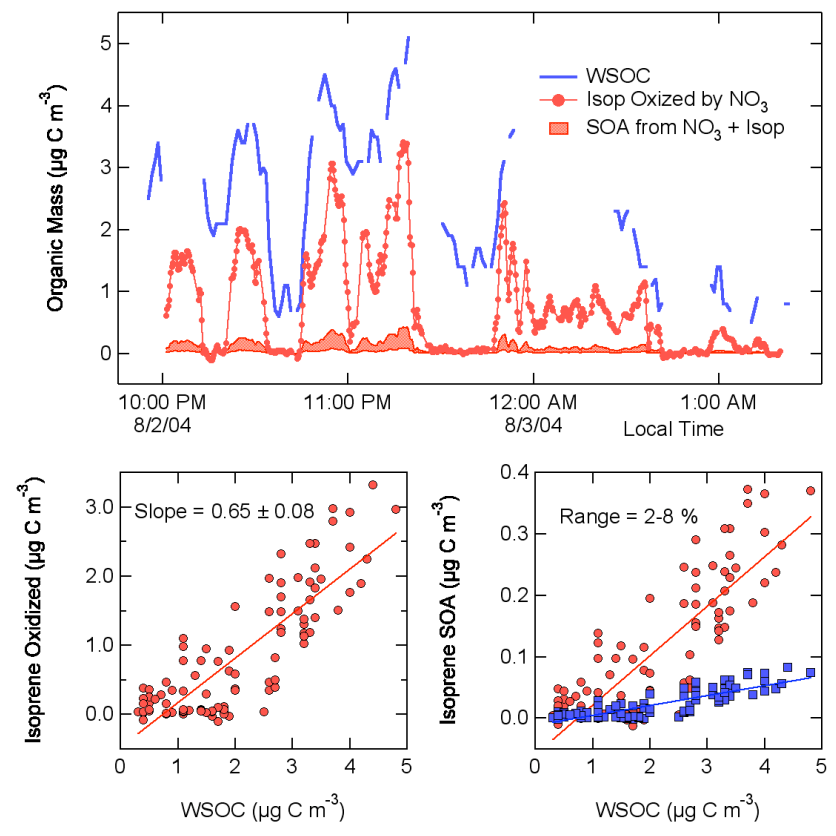

Fig. 10. Top: Time series from the 3 August flight of water soluble organic carbon (WSOC), nocturnally oxidized isoprene (in $\mu \mathrm{g} \mathrm{C} \mathrm{m}^{-3}$, same axis) and secondary organic aerosol (SOA) derived from that isoprene using yields from $\mathrm{Ng}$ et al., (2008). The uncertainty in the shaded region is due to the range of aerosol yields (2.5-12.5\% carbon mass, see text) and does not reflect the $\pm 50 \%$ uncertainty in the derived nighttime isoprene oxidation. The full uncertainty is given in Table 3. Bottom: Plots of nocturnally oxidized isoprene (left) and isoprene-SOA against WSOC from the data in the top graph. Blue squares and red circles on the bottom right graph show the correlation of isoprene SOA against WSOC for 2.5 and $12.5 \%$ yields, giving a 2 and $8 \%$ contribution to observed WSOC, respectively.

tracers for anthropogenic emissions, such as acetylene, but that budgets of organic aerosol production are poorly represented by current understanding based on yields for individual VOCs measured in smog chambers (de Gouw et al., 2005, 2008; Quinn et al., 2006; Sullivan et al., 2006). The contribution of biogenic VOCs to organic aerosol production remains uncertain, although recent analysis of radiocarbon in organic aerosol has suggested that a large fraction comes from biogenic sources, even in areas with large anthropogenic VOC emissions (Bench et al., 2007; Schichtel et al., 2008; Weber et al., 2007). Because the yield of SOA from the $\mathrm{NO}_{3}+$ isoprene reaction ( $\mathrm{Ng}$ et al., 2008) is some 5-8× larger than from photochemical isoprene oxidation (Kroll et al., 2005), its nighttime oxidation is a mechanism by which biogenic VOCs can more efficiently form SOA in polluted air masses. Furthermore, since $\mathrm{NO}_{3}$ is derived from $\mathrm{NO}_{\mathrm{x}}$ and is an anthropogenic oxidant, aerosol produced via this oxidation would correlate with anthropogenic tracers, but maintain a biogenic carbon signature. 
Table 3. Reactive nitrogen partitioning and contribution of isoprene oxidation products to SOA.

\begin{tabular}{ccccc}
\hline Date & Isop Nitrate/NO $(\%)$ & Isop Nitrate/Isop Nitrate+PAN $(\%)$ & Isop SOA/ WSOC (\%) & NO $_{3}$-Isop SOA/Total Isop SOA $(\%)^{\mathrm{b}}$ \\
\hline 11 July & $3 \pm 2$ & $7 \pm 4$ & $<2$ & 31 \\
31 July & $6 \pm 5$ & $26 \pm 22$ & $0.5-17$ & 56 \\
2-3 Aug & $4 \pm 2$ & $16 \pm 8$ & $1-12$ & 60 \\
7-8 Aug & $8 \pm 4$ & $31 \pm 15$ & $1-15$ & 86 \\
9-10 Aug a & $6 \pm 4$ & $26 \pm 17$ & $0.5-6$ & 57 \\
Average & $6 \pm 4 \%$ & $21 \pm 18 \%$ & $1-11 \%$ & $58 \pm 17 \%$ \\
\hline
\end{tabular}

${ }^{a}$ Data for Northeast US portion of this flight only ${ }^{b}$ Total isoprene SOA considers that resulting from gas-phase $\mathrm{OH}_{2} \mathrm{O}_{3}$ and $\mathrm{NO}_{3}$ oxidation but not SOA formed from, for example, heterogeneous reactions of isoprene.

Figure 10 shows the time series for organic aerosol, measured as water soluble organic carbon (WSOC) with a particle into liquid sampler (PiLS) (Table 1), for the $3 \mathrm{Au}$ gust flight. Shown together on the same scale is the calculated amount of isoprene oxidized after dark, converted to the same units $\left(\mu \mathrm{g} \mathrm{C} \mathrm{m}^{-3}\right)$. The two quantities are similar in magnitude (oxidized isoprene was $65 \%$ of WSOC) and reasonably well correlated, as the lower left plot shows. It is important to note, however, that WSOC was also well correlated with other anthropogenic tracers (e.g., $\mathrm{CO}$ ) such that the correlation in the lower left plot of Fig. 10 does not suggest that the majority of SOA was attributable to nighttime isoprene oxidation. Indeed, the smaller, shaded region in the upper graph of Fig. 10 shows nocturnally oxidized isoprene multiplied by the range of $\mathrm{SOA}$ yields for $\mathrm{NO}_{3}+$ isoprene from the recent chamber study (Ng et al., 2008). The range from the chamber study is given as aerosol mass produced per unit mass of parent hydrocarbon oxidized. Conversion from total mass to carbon mass requires the molecular weight of the condensing species. Under the assumption that the condensable products are carbonyl nitrates, with a formula $\mathrm{C}_{5} \mathrm{H}_{7} \mathrm{O}_{4} \mathrm{~N}$, the organic mass yield of $5-25 \%$ from the smog chamber is equivalent to an organic carbon yield of $2.5-12.5 \%$. The predicted nocturnal isoprene SOA is plotted against observed WSOC in the lower right hand plot. The slopes of this graph give a range of $2-8 \%$ of measured WSOC attributable to nocturnally oxidized isoprene.

Although this analysis shows only a small contribution (typically $<10 \%$ ) of nighttime isoprene oxidation to total observed organic aerosol, the SOA mass derived from nighttime isoprene oxidation was large in comparison to that predicted from daytime isoprene oxidation. Figure 11 shows this calculation, again using the 3 August flight as an example. Although the amount of isoprene oxidized after dark was smaller than that oxidized photochemically, the laboratory mass yields for $\mathrm{NO}_{3}$-isoprene reactions are larger than those for $\mathrm{OH}-$ or $\mathrm{O}_{3}$-isoprene reaction, such that in this regionally polluted environment $\mathrm{NO}_{3}$ was calculated to have made a larger contribution. Figure 11 shows the calculated isoprene SOA mass (as total rather than carbon mass) from

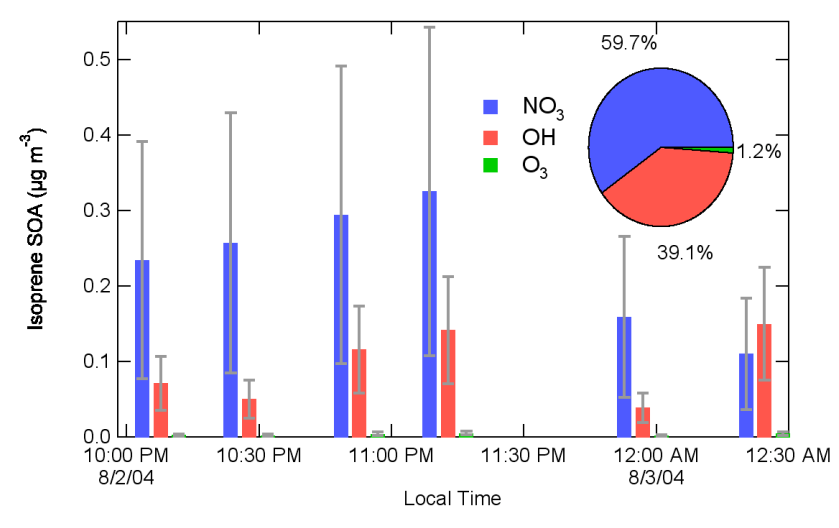

Fig. 11. Calculated isoprene SOA mass for the 3 August flight due to $\mathrm{NO}_{3}, \mathrm{OH}$ and $\mathrm{O}_{3}$. Sticks with error bars give average mass and uncertainty for different sampled air masses, and the pie chart gives the relative integrated contribution of each oxidant for the entire flight as percentages. Error bars reflect only the uncertainty in mass yields and not the uncertainties due to the FLEXPART isoprene calculation or the determination of the nighttime oxidized isoprene mass (see text).

each oxidant averaged for each of the sampled air masses on 3 August. The $\mathrm{NO}_{3}$-isoprene SOA mass is the product of the isoprene mass oxidized after dark by $\mathrm{NO}_{3}$ and the laboratory SOA mass yield, taken here as $15 \pm 10 \%$ (for the $5-25 \%$ range given) (Ng et al., 2008). Similarly, the OHisoprene SOA mass is the difference between the FLEXPART integrated isoprene emission for each air mass and the amount oxidized after dark times the laboratory yield of $2 \pm 1 \%$ (range of $0.9-3 \%$ ) (Kroll et al., 2005). Finally, the $\mathrm{O}_{3}$-isoprene SOA mass is taken as $5 \%$ of the total isoprene emission times its laboratory SOA yield (1\%) (Kleindienst et al., 2007). The calculated $\mathrm{OH}$ and $\mathrm{NO}_{3}$ isoprene $\mathrm{SOA}$ mass totals take into account the amount of isoprene oxidized by $\mathrm{O}_{3}$. The contribution of $\mathrm{NO}_{3}$ to the total isoprene SOA is approximately $50 \%$ greater than $\mathrm{OH}$ in this regionally polluted area. However, this does not consider other possible routes for SOA formation from isoprene, such as heterogeneous reactions (Altieri et al., 2006; Ervens et al., 2008; Liggio et al., 

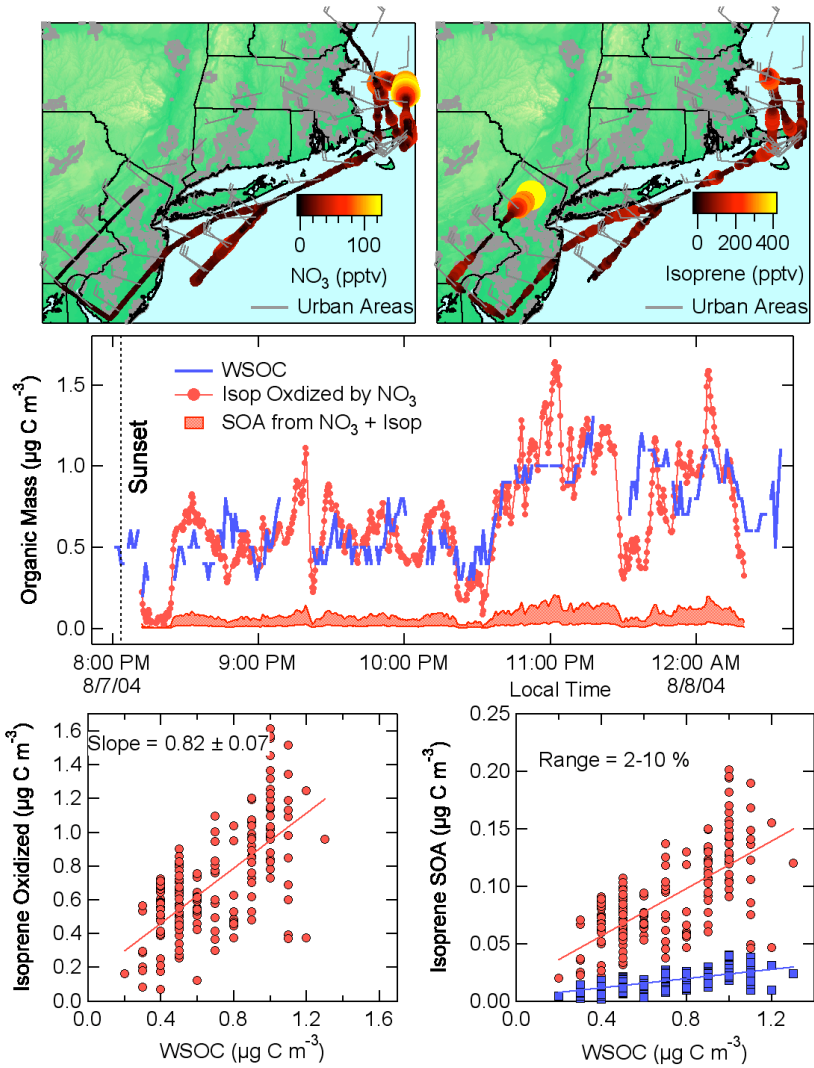

Fig. 12. Same as Fig. 10, except for the 7 August flight. The maps in the top panels shows the after-sunset portion of the flight track, color and size coded by $\mathrm{NO}_{3}$ (left) and isoprene (right).

2007), or the dependence of aerosol yields on other variables such as temperature and relative humidity.

Analysis of several other flights showed correlations between nocturnally oxidized isoprene and observed WSOC, non-negligible contributions of $\mathrm{NO}_{3}$-isoprene $\mathrm{SOA}$ to total organic aerosol, and large nighttime isoprene-SOA compared to photochemical isoprene-SOA, as shown in Table 3. Figure 12 gives one additional example, from the night flight on 7 August which sampled mainly along the coastline from New Jersey to Massachusetts under conditions of offshore flow. In this case, there was a small organic aerosol loading, $0.5-1.5 \mu \mathrm{g} \mathrm{C} \mathrm{m}^{-3}$, but it was again well correlated and of the same magnitude as the isoprene oxidized after dark. The fraction of secondary organic aerosol attributable to oxidized isoprene was $2-10 \%$. Analysis of the 31 July flight showed a similar result, although the determination of isoprene oxidized after dark was much less certain (see Table 2). By contrast, flights in which the background organic aerosol loading was already substantial (e.g., 11 July, 9 August) showed only small amounts of observed organic aerosol attributable to nocturnal isoprene oxidation $(<4 \%)$, even though there was a comparable amount of isoprene oxidized on these flights. In these cases, the correlations between oxidized isoprene and
WSOC were poor. These observations suggest that the signature of nocturnally-produced isoprene SOA is most apparent when the background aerosol concentrations are small. Photochemical production of organic aerosol from anthropogenic VOC on the preceding day has the capacity to produce much larger amounts of organic aerosol than nighttime processes (e.g., de Gouw et al., 2005, 2008), so that the influence of nighttime chemistry on SOA becomes less apparent if the daytime, background SOA loading is large. Nevertheless, the derived isoprene-SOA from $\mathrm{NO}_{3}$, ranging up to $17 \%$ of observed organic aerosol and in many cases dominating the SOA derived from isoprene (see Table 3 ), is a source that may need to be accounted for in models if these results are borne out by further work and if current understanding of SOA yields is correct.

\section{Summary and conclusions}

This paper has examined nighttime oxidation of isoprene in air masses sampled from an aircraft within the residual daytime boundary layer during the summer of 2004 in the Northeast US. Results from this study are applicable to isoprene oxidation occurring at night within the daytime residual boundary layer $(\sim 0.1-1.5 \mathrm{~km})$ during summertime in a polluted, forested region. Other biogenic VOCs, particularly monoterpenes, were not addressed here because they were not observed in large concentration from the aircraft. However, nocturnal oxidation of these hydrocarbons is rapid via both $\mathrm{O}_{3}$ and $\mathrm{NO}_{3}$, such that their oxidation rates and production of organic nitrates and secondary organic aerosol should be strongly influenced by regional $\mathrm{NO}_{\mathrm{x}}$ pollution (Fry et al., 2009; Hallquist et al., 1999). Because monoterpene oxidation is temperature but not sunlight dependent, and because these compounds are more reactive with both ozone and $\mathrm{NO}_{3}$, the signature of their oxidation should be most apparent within the nocturnal boundary layer. As a result, their nocturnal oxidation products may be both more concentrated and more vertically stratified. Study of these oxidation processes will be of considerable future interest but may require vertically resolved measurements above $\mathrm{NO}_{\mathrm{x}}$-impacted forest canopies.

Acknowledgements. The authors thank the crew of the NOAA P-3 for their dedication and professionalism. This work was supported by the NOAA Atmospheric Chemistry and Climate and Health of the Atmosphere Programs and the New England Air Quality Study.

Edited by: J. W. Bottenheim 


\section{References}

Aldener, M., Brown, S. S., Stark, H., Williams, E. J., Lerner, B. M., Kuster, W. C., Goldan, P. D., Quinn, P. K., Bates, T. S., Fehsenfeld, F. C., and Ravishankara, A. R.: Reactivity and loss mechanisms of $\mathrm{NO}_{3}$ and $\mathrm{N}_{2} \mathrm{O}_{5}$ in a marine environment: results from in-situ measurements during NEAQS 2002, J. Geophys. Res., 111, D23S73, doi:10.1029/2006JD007252, 2006.

Allan, B. J., McFiggans, G., Plane, J. M. C., Coe, H., and McFadyen, G. G.: The nitrate radical in the remote marine boundary layer, J. Geophys. Res., 105, 24191-24204, 2000.

Altieri, K. E., Carlton, A. G., Lim, H.-J., Turpin, B. J., and Seitzinger, S. P.: Evidence for oligomer formation in clouds: Reaction of isoprene oxidation products, Environ. Sci. Technol., 40, 4956-4960, 2006.

Ambrose, J. L., Mao, H., Mayne, H. R., Stutz, J., Talbot, R., and Sive, B. C.: Nighttime nitrate radical chemistry at Appledore Island, Maine during the 2004 International Consortium for Atmospheric Research on Transport and Transformation, J. Geophys. Res., 112, D21302, doi:10.1029/2007JD008756, 2007.

Apel, E., Riemer, D. D., Hills, A., Baugh, W., Orlando, J., Faloona, I., Tan, D., Brune, W., Lamb, B., Westberg, H., Carroll, M. A., Thornberry, T., and Geron, C.: Measurement and interpretation of isoprene fluxes and isoprene, methacrolein, and methyl vinyl ketone mixing ratios at the PROPHET site during the 1998 Intensive, J. Geophys. Res., 107, 4034, doi:10.1029/2000JD000225, 2002.

Atkinson, R. and Arey, J.: Gas-phase tropospheric chemistry of biogenic volatile organic compounds: a review, Atmos. Environ., 37, S197-S219, 2003.

Barnes, I., Bastian, V., Becker, K. H., and Tong, Z.: Kinetics and Products of the Reactions of $\mathrm{NO}_{3}$ with Monoalkenes, Dialkenes, and Monoterpenes, J. Phys. Chem., 94, 2413-2419, 1990.

Bench, G., Fallon, S., Schichtel, B., Malm, W., and McDade, C.: Relative contributions of fossil and contemporary carbon sources to PM 2.5 aerosols at nine Interagency Monitoring for Protection of Visual Envioronments (IMPROVE) network sites, J. Geophys. Res., 112, D10205, doi:10.1029/2006JD007708, 2007.

Berndt, T. and Boge, O.: Gas-phase reaction of $\mathrm{NO}_{3}$ radicals with isoprene: A kinetic and mechanistic study, Int. J. Chem. Kin., 29, 755-765, 1997.

Biesenthal, T., Bottenheim, J. W., Shepson, P. B., Li, S. M., and Brickell, P. C.: The chemistry of biogenic hydrocarbons at a rural site in eastern Canada, J. Geophys. Res., 103, 25487-25498, 1998.

Brown, S. S., Stark, H., and Ravishankara, A. R.: Applicability of the Steady-State Approximation to the Interpretation of Atmospheric Observations of $\mathrm{NO}_{3}$ and $\mathrm{N}_{2} \mathrm{O}_{5}$, J. Geophys. Res., 108, D174539, doi:10.1029/2003JD003407, 2003.

Brown, S. S., Dibb, J. E., Stark, H., Aldener, M., Vozella, M., Whitlow, S., Williams, E. J., Lerner, B. M., Jakoubek, R., Middlebrook, A. M., DeGouw, J. A., Warneke, C., Goldan, P. D., Kuster, W. C., Angevine, W. M., Sueper, D. T., Quinn, P. K., Bates, T. S., Meagher, J. F., Fehsenfeld, F. C., and Ravishankara, A. R.: Nighttime removal of $\mathrm{NO}_{\mathrm{x}}$ in the summer marine boundary layer, Geophys. Res. Lett., 31, L07108, doi:10.1029/2004GL019412, 2004.

Brown, S. S., Neuman, J. A., Ryerson, T. B., Trainer, M., Dubé, W. P., Holloway, J. S., Warneke, C., de Gouw, J. A., Donnelly, S. G., Atlas, E., Matthew, B., Middlebrook, A. M., Peltier, R.,
Weber, R. J., Stohl, A., Meagher, J. F., Fehsenfeld, F. C., and Ravishankara, A. R.: Nocturnal odd-oxygen budget and its implications for ozone loss in the lower troposphere, Geophys. Res. Lett., 33, L08801, doi:10.1029/2006GL025900, 2006a.

Brown, S. S., Ryerson, T. B., Wollny, A. G., Brock, C. A., Peltier, R., Sullivan, A. P., Weber, R. J., Dubé, W. P., Trainer, M., Meagher, J. F., Fehsenfeld, F. C., and Ravishankara, A. R.: Variability in nocturnal nitrogen oxide processing and its role in regional air quality, Science, 311, 67-70, 2006b.

Brown, S. S., Dubé, W. P., Osthoff, H. D., Stutz, J., Ryerson, T. B., Wollny, A. G., Brock, C. A., Warneke, C., de Gouw, J. A., Atlas, E., Neuman, J. A., Holloway, J. S., Lerner, B. M., Williams, E. J., Kuster, W. C., Goldan, P. D., Angevine, W. M., Trainer, M., Fehsenfeld, F. C., and Ravishankara, A. R.: Vertical profiles in $\mathrm{NO}_{3}$ and $\mathrm{N}_{2} \mathrm{O}_{5}$ measured from an aircraft: Results from the NOAA P-3 and surface platforms during NEAQS 2004, J. Geophys. Res., 112, D22304, doi: 10.1029/2007JD008883, 2007.

Chen, X., Hulbert, D., and Shepson, P. B.: Measurement of the organic nitrate yield from $\mathrm{OH}$ reaction with isoprene, J. Geophys. Res., 103, 25563-25568, 1998.

Claeys, M., Graham, B., Vas, G., Wang, W., Vermeylen, R., Pashynska, V., Cafmeyer, J., Guyon, P., Andreae, M. O., Artaxo, P., and Maenhaut, W.: Formation of Secondary Organic Aerosols Trhough Photooxidation of Isoprene, Science, 303, 1173-1176, 2004.

de Gouw, J. A., Goldan, P. D., Warneke, C., Kuster, W. C., Roberts, J. M., Marchewka, M., Bertman, S. B., Pszenny, A. A. P., and Keene, W. C.: Validation of proton transfer reaction-mass spectrometry (PTR-MS) measurements of gas-phase organic compounds in the atmosphere during the New England Air Quality Study (NEAQS) in 2002, J. Geophys. Res., 108, D214682, doi:10.1029/2003JD003863, 2003.

de Gouw, J. A., Middlebrook, A. M., Warneke, C., Goldan, P. D., Kuster, W. C., Roberts, J. M., Fehsenfeld, F. C., Worsnop, D. R., Canagaratna, M. R., Pszenny, A. A. P., Keene, W. C., Marchewka, M., Bertman, S. B., and Bates, T. S.: Budget of organic carbon in a polluted atmosphere: Results from the New England Air Quality Study in 2002, J. Geophys. Res.-Atmos., 110, D16305, doi:10.1029/2004JD005623, 2005.

de Gouw, J. A. and Warneke, C.: Measurements of volatile organic compounds in the Earth's atmosphere using proton-transferreaction mass spectrometry, Mass. Spec. Rev., 26, 223-257, 2007.

de Gouw, J. A., Brock, C. A., Atlas, E., Bates, T. S., Fehsenfeld, F. C., Goldan, P. D., Holloway, J. S., Kuster, W. C., Lerner, B. M., Matthew, B. M., Middlebrook, A. M., Onasch, T. B., Peltier, R. E., Quinn, P. K., Senff, C. J., Stohl, A., Sullivan, A. P., Trainer, M., Warneke, C., Weber, R. J., and Williams, E. J.: Sources of particulate matter in the northeastern United States in summer: 1. Direct emission and secondary formation of organic matter in urban plumes, J. Geophys. Res., 113, D08301, doi:10.1029/2007JD009243, 2008.

Dubé, W. P., Brown, S. S., Osthoff, H. D., Nunley, M. R., Ciciora, S. J., Paris, M. W., McLaughlin, R. J., and Ravishankara, A. R.: Aircraft instrument for simultaneous, in-situ measurements of $\mathrm{NO}_{3}$ and $\mathrm{N}_{2} \mathrm{O}_{5}$ via cavity ring-down spectroscopy, Rev. Sci. Instr., 77, 034101, doi:10.1063/1061.2176058, 2006.

Ervens, B., Carlton, A. G., Turpin, B. J., Altieri, K. E., Kreidenwies, S. m., and Feingold, G.: Secondary organic aerosol yields from 
cloud-processing of isoprene oxidation products, Geophys. Res. Lett., 35, L02816, doi:10.1029/2007GL031828, 2008.

Fan, F. and Zhang, R.: Atmospheric Oxidation Mechanism of Isoprene, Environ. Chem., 1, 140-149, 2004.

Fehsenfeld, F. C., Ancellet, G., Bates, T. S., Goldstein, A. H., Hardesty, R. M., Honrath, R., Law, K., Lewis, A. C., Leaitch, R., McKeen, S. A., Meagher, J., Parrish, D. D., Pszenny, A. A. P., Russel, P. B., Schlager, H., Seinfeld, J. H., Talbot, R., and Zbinden, R.: International Consortium for Atmospheric Research on Transport and Transformation (ICARTT): North America to Europe - Overview of the 2004 summer field study, J. Geophys. Res., 111, D23S01, doi:10.1029/2006JD007829, 2006.

Fischer, R. G., Kaster, J., and Ballschmitter, K.: Levels and pattern of alkyl nitrates, multifunctional alkyl nitrates, and halocarbons in the air over the Atlantic Ocean, J. Geophys. Res., 105, 1447314494, 2000.

Fry, J. L., Kiendler-Scharr, A., Rollins, A. W., Wooldridge, P. J., Brown, S. S., Fuchs, H., Dubé, W. P., Mensah, A., dal Maso, M., Tillmann, R., Dorn, H.-P., Brauers, T., and Cohen, R. C.: Organic nitrate and secondary organic aerosol yield from $\mathrm{NO}_{3}$ oxidaiton of $\beta$-pinene evaluated using a gas-phase kinetics/aerosol partitioning model, Atmos. Chem. Phys., 9, 1431-1449, 2009, http://www.atmos-chem-phys.net/9/1431/2009/.

Fuchs, H., Dubé, W. P., Ciciora, S. J., and Brown, S. S.: Determination of Inlet Transmission and Conversion Efficiencies for in Situ Measurements of the Nocturnal Nitrogen Oxides, $\mathrm{NO}_{3}$, $\mathrm{N}_{2} \mathrm{O}_{5}$ and $\mathrm{NO}_{2}$, via Pulsed Cavity Ring-Down Spectroscopy, Anal. Chem., 80, 6010-6017, doi:10.1021/ac8007253, 2008.

Fuentes, J. D., Lerdau, M., Atkinson, R., Baldocchi, D., Bottenheim, J. W., Ciccioli, P., Lamb, B., Geron, C., Gu, L., Guenther, A., Sharkey, T. D., and Stockwell, W.: Biogenic Hydrocarbons in the Atmospheric Boundary Layer: A Review, B. Am. Meteor. Soc., 81, 1537-1575, 2000.

Geyer, A., Ackermann, R., Dubois, R., Lohrmann, B., Müller, R., and Platt, U.: Long-term observation of nitrate radicals in the continental boundary layer near Berlin, Atmos. Environ., 35, 3619-3631, 2001.

Geyer, A. and Platt, U.: Temperature dependence of the $\mathrm{NO}_{3}$ loss frequency: A new indicator for the contribution of $\mathrm{NO}_{3}$ to the oxidation of monoterpenes and NOx removal in the atmosphere, J. Geophys. Res., 107, D214431, doi:10.1029/2001JD001215, 2002.

Giacopelli, P., Ford, K., Espada, C., and Shepson, P. B.: Comparison of the measured and simulated isoprene nitrate distributions above a forest canopy, J. Geophys. Res., 110, D01304, doi:10.1029/2004JD005123, 2005.

Grossenbacher, J. W., Couch, T., Shepson, P. B., Thornberry, T., Witmer-Rich, M., Carroll, M. A., Faloona, I., Tan, D., Brune, W., Ostling, K., and Bertman, S.: Measurements of isoprene nitrates above a forest canopy, J. Geophys. Res., 106, 2442924438, 2001.

Grossenbacher, J. W., Barket, D. J., Shepson, P. B., Carroll, M. A., Olszyna, K., and Apel, E.: A comparison of isoprene nitrate concentrations at two forest-impacted sites, J. Geophys. Res., 109, D11311, doi:10.1029/2003JD003966, 2004.

Guenther, A., Karl, T., Harley, P., Wiedinmyer, C., Palmer, P. I., and Geron, C.: Estimates of global terrestrial isoprene emissions using MEGAN (Model of Emissions of Gases and Aerosols from
Nature), Atmos. Chem. Phys., 6, 3181-3210, 2006, http://www.atmos-chem-phys.net/6/3181/2006/.

Hallquist, M., Wängberg, I., Ljungstrom, E., Barnes, I., and Becker, K. H.: Aerosol and Product Yields from $\mathrm{NO}_{3}$ Radical-Initiated Oxidation of Selected Monoterpenes, Environ. Sci. Technol., 33, 553-559, 1999.

Henze, D. K. and Seinfeld, J. H.: Global secondary organic aerosol from isoprene oxidation, Geophys. Res. Lett., 33, L09812, doi:10.1029/2006GL025976, 2006.

Horowitz, L. W., Fiore, A. M., Milly, G. P., Cohen, R. C., Perrin, A., Wooldridge, P. J., Hess, P. G., Emmons, L. K., and Lamarque, J. F.: Observational constraints on the chemistry of isoprene nitrates over the eastern United States, J. Geophys. Res., 112, D12S08, doi:10.1029/2006JD007747, 2007.

Hurst, J. M., Barket, D. J., Herrera-Gomez, O., Couch, T. L., Shepson, P. B., Faloona, I., Tan, D., Brune, W., Westberg, H., Lamb, B., Biesenthal, T., Young, V., Goldstein, A., Munger, J. W., Thornberry, T., and Carroll, M. A.: Investigation of the nighttime decay of isoprene, J. Geophys. Res.-Atmos., 106, 24335-24346, 2001.

Kim, S.-W., Heckel, A., McKeen, S. A., Frost, G. J., Hsie, E. Y., Trainer, M. K., Richter, A., Burrows, J. P., Peckham, S. E., and Grell, G. A.: Satellite-observed US power plant NOx emission reductions and their impact on air quality, Geophys. Res. Lett., 33, L22812, doi:10.1029/2006GL027749, 2006.

Kleindienst, T. E., Lewandowski, M., Offenberg, J. H., Jaoui, M., and Edney, E. O.: Ozone-isoprene reaction: Re-examination of the formation of secondary organic aerosol, Geophys. Res. Lett., 34, L01805, doi:10.1029/2006GL027485, 2007.

Kroll, J. H., Ng, N. L., Murphy, S. M., Flagan, R. C., and Seinfeld, J. H.: Secondary organic aerosol formation from isoprene photooxidation under high- $\mathrm{NO}_{\mathrm{x}}$ conditions, Geophys. Res. Lett., 32, L18808, doi:10.1029/2005GL023637, 2005.

Kwok, E. S. C., Aschmann, S. M., Arey, J., and Atkinson, R.: Product formation from the reaction of the $\mathrm{NO}_{3}$ radical with isoprene and rate constants for the reactions of methacrolein and methyl vinyl ketone with the $\mathrm{NO}_{3}$ radical, Int. J. Chem. Kin., 28, 925 934, 1996.

Lelieveld, J., Butler, T. M., Crowley, J. N., Dillon, T. J., Fischer, H., Ganzveld, L., Harder, H., Lawrence, M. G., Martinez, M., Taraborrelli, D., and Williams, J.: Atmospheric oxidation capacity sustained by a tropical forest, Nature, 452, 737-740, 2008.

Liggio, J., Li, S.-M., Brook, J. R., and Mihele, C. M.: Direct polymerization of isoprene and a-pinene on acidic aerosols, Geophys. Res. Lett., 34, L05814, doi:10.1029/2006GL028468, 2007.

McLaren, R., Salmon, R. A., Liggio, J., Hayden, K. L., Analuf, K., and Leaitch, W. R.: Nighttime chemistry at a rural site in the Lower Fraser Valley, Atmos. Environ., 38, 5837-5848, 2004.

Neuman, J. A., Huey, L. G., Dissly, R. W., Fehsenfeld, F. C., Flocke, F., Holecek, J. C., Holloway, J. S., Hübler, G., Jakoubek, R., Nicks, D. K., Jr., Parrish, D. D., Ryerson, T. B., Sueper, D. T., and Weinheimer, A. J.: Fast-response airborne in situ measurements of HNO3 during the Texas 2000 Air Quality Study, J. Geophys. Res., 107, 4436, doi:10.1029/2001JD001437, 2002.

Neuman, J. A.: Reactive nitrogen transport and photochemistry in urban plumes over the North Atlantic Ocean, J. Geophys. Res., 111, D23S54, doi:10.1029/2005JD007010, 2006.

Ng, N. L., Kwan, A. J., Surratt, J. D., Chan, A. W. H., Chhabra, P. S., Sorooshian, A., Pye, H. O. T., Crounse, J. D., Wennberg, P. 
O., Flagan, R. C., and Seinfeld, J. H.: Secondary organic aerosol (SOA) formation from reaction of isoprene with nitrate radicals $\left(\mathrm{NO}_{3}\right)$, Atmos. Chem. Phys., 8, 4117-4140, 2008, http://www.atmos-chem-phys.net/8/4117/2008/.

Olivier, J. G. J. and Berdowski, J. J. M.: Global emissions sources and sinks, in: The Climate System, edited by: Berdowski, J., Guicherit, R., and Heij, B. J., A. A. Balkema, The Netherlands, 33-78, 2001.

Paulson, S. E. and Seinfeld, J. H.: Development and Evaluation of a Photooxidation Mechnaism for Isoprene, J. Geophys. Res., 97, 20703-20715, 1992.

Platt, U. F., Winer, A. M., Bierman, H. W., Atkinson, R., and Pitts Jr., J. N.: Measurement of Nitrate Radical Concentrations in Continental Air, Environ. Sci. Technol., 18, 365-369, 1984.

Poisson, N., Kanakidou, M., and Crutzen, P. J.: Impact of NonMethane Hydrocarbons on Tropospheric Chemistry and the Oxidizing Power of the Global Troposphere: 3-Dimensional Modelling Results, J. Atmos. Chem., 36, 157-230, 2000.

Quinn, P. K., Bates, T. S., Coffman, D., Onasch, T. B., Worsnop, D. R., Baynard, T., de Gouw, J. A., Goldan, P. D., Kuster, W. C., Williams, E., Roberts, J. M., Lerner, B. M., Stohl, A., Pettersson, A., and Lovejoy, E. R.: Impacts of sources and aging on submicrometer aerosol prperties in the marine boundary layer across the Gulf of Maine, J. Geophys. Res., 111, D23S36, doi:10.1029/2006JD007582, 2006.

Ryerson, T. B., Huey, L. G., Knapp, K., Neuman, J. A., Parrish, D. D., Sueper, D. T., and Fehsenfeld, F. C.: Design and initial characterization of an inlet for gas-phase $\mathrm{NO}_{\mathrm{y}}$ measurements from aircraft, J. Geophys. Res., 104, 5483-5492, 1999.

Ryerson, T. B., Williams, E. J., and Fehsenfeld, F. C.: An efficient photolysis system for fast response $\mathrm{NO}_{2}$ measurements, J. Geophys. Res., 105, 26447-26461, 2000.

Schauffler, S. M., Atlas, E., Blake, D. R., Flocke, F., Lueb, R. A., Lee-Taylor, J. M., Stroud, V., and Travnicek, W.: Distributions of brominated organic compounds in the troposphere and lower stratosphere, J. Geophys. Res., 104, 21513-21536, 1999.

Schichtel, B., Malm, W. C., Bench, G., Fallon, S., McDade, C. E., Chow, J. C., and Watson, J. G.: Fossil and contemporary fine particulate carbon fractions at 12 rural and urban sites in the United States, J. Geophys. Res., 113, D02311, doi:10.1029/2007JD008605, 2008.

Sillman, S., Carroll, M. A., Thornberry, T., Lamb, B. K., Westberg, H., Brune, W. H., Faloona, I., Tan, D., Shepson, P. B., Sumner, A. L., Hastie, D. R., Mihele, C. M., Apel, E. C., Riemer, D. D., and Zika, R. G.: Loss of isoprene and sources of nighttime $\mathrm{OH}$ radicals at a rural site in the United States: Results from photochemical models, J. Geophys. Res., 107, 4043, doi:10.1029/2001JD000449, 2002.

Skamarock, W. C., Klemp, J. B., Dudhia, J., Gill, D. O., Barker, D. M., Duda, M. G., Huang, X. Y., Wang, W., and Powers, J. G.: A description of the advanced research WRF version 3, National Center for Atmospheric Research Technical Note, NCAR/TN-475+STR, http://www.mmm.ucar.edu/wrf/ users/docs/arw_v3.pdf, 2008.

Skov, H., Hjorth, J., Lohse, C., Jensen, N. R., and Restelli, G.: Products and mechanisms of the reactions of the nitrate racidal $\left(\mathrm{NO}_{3}\right)$ with isoprene, 1,3-butadiene and 2,3-dimethyl-1,3,butadiene in air, Atmos. Environ., 26A, 2771-2783, 1992.

Skov, H., Benter, T., Schindler, R. N., Hjorth, J., and Restelli, G.:
Epoxide Formation in the Reactions of the Nitrate Radical with 2,3-Dimethyl-2-Butene, Cis-2-Butene and Trans-2-Butene and Isoprene, Atmos. Environ., 28, 1583-1592, 1994.

Slusher, D. L., Huey, L. G., Tanner, D. J., Flocke, F., and Roberts, J. M.: A thermal dissociation - chemical ionization mass sepctrometry (TD-CIMS) technique for the simultaneous measurement of peroxyacetyl radicals and dinitrogen pentoxide, J. Geophys. Res., 109, D19315, doi:10.1029/2004JD004670, 2004.

Sommariva, R., Osthoff, H. D., Brown, S. S., Bates, T. S., Baynard, T., Coffman, D., de Gouw, J. A., Goldan, P. D., Kuster, W. C., Lerner, B. M., Stark, H., Warneke, C., Williams, E. J., Fehsenfeld, F. C., Ravishankara, A. R., and Trainer, M.: Radicals in the marine boundary layer during NEAQS 2004: a model study of day-time and night-time sources and sinks, Atmos. Chem. Phys. Discuss., 8, 16643-16692, 2008,

http://www.atmos-chem-phys-discuss.net/8/16643/2008/.

Sprengnether, M. M., Demerjian, K. L., Donahue, N. M., and Anderson, J. G.: Product analysis of the $\mathrm{OH}$ oxidation of isoprene and 1,3-butadiene in the presence of NO, J. Geophys. Res., 107, 4268, doi:10.1029/2001JD000716, 2002.

Starn, T. K., Shepson, P. B., Bertman, S. B., Reimer, D. D., Zika, R. G., and Olszyna, K.: Nighttime isoprene chemistry at an urbanimpacted forest site, J. Geophys. Res., 103, 22437-22447, 1998.

Steinbacher, M., Dommen, J., Ordonez, C., Reimann, S., Grüebler, F. C., Staehelin, J., Andreani-Aksoyoglu, S., and Prevot, A. S. H.: Volatile Organic Compounds in the Po Basin. Part B: Biogenic VOCs, J. Atmos. Chem., 51, 293-315, doi:10.1007/s10874-0053577-0, 2005.

Stohl, A., Forster, C., Frank, A., Seibert, P., and Wotawa, G.: The Lagrangian particle dispersion model FLEXPART version 6.2, Atmos. Chem. Phys., 5, 2461-2474, 2005, http://www.atmos-chem-phys.net/5/2461/2005/.

Stroud, C. A., Roberts, J. M., Williams, E. J., Hereid, D., Angevine, W. M., Fehsenfeld, F. C., Wisthaler, A., Hansel, A., MartinezHarder, M., Harder, H., Brune, W. H., Hoenninger, G., Stutz, J., and White, A. B.: Nighttime isoprene trends at an urban forested site during the 1999 Southern Oxidants Study, J. Geophys. Res., 107, 4291, doi:10.1029/2001JD000959, 2002.

Stutz, J., Alicke, B., Ackermann, R., Geyer, A., White, A. B., and Williams, E.: Vertical profiles of $\mathrm{NO}_{3}, \mathrm{~N}_{2} \mathrm{O}_{2}, \mathrm{O}_{3}$, and $\mathrm{NO}_{\mathrm{X}}$ in the nocturnal boundary layer: 1 . Observations during the Texas Air Quality Study 2000, J. Geophys. Res., 109, D12306, doi:10.1029/2003JD004209, 2004.

Sullivan, A. P., Peltier, R. E., Brock, C. A., de Gouw, J. A., Holloway, J. S., Warneke, C., Wollny, A. G., and Weber, R. J.: Airborne measurements of carbonaceous aerosol soluble in water over the northeastern United States: Method development and an investigation into water-soluble organic carbon sources, J. Geophys. Res., 111, D23S46, doi:10.1029/2006JD007072, 2006.

Trainer, M., Williams, E. J., Parrish, D. D., Buhr, M. P., Allwine, E. J., Westberg, H. H., Fehsenfeld, F. C., and Liu, S. C.: Models and observations of the impact of natural hydrocarbons on rural ozone, Nature, 329, 705-707, 1987.

Trainer, M., Buhr, M. P., Curran, C. M., Fehsenfeld, F. C., Hsie, E. Y., Liu, S. C., Norton, R. B., Parrish, D. D., Williams, E. J., Gandrud, B. W., Ridley, B. A., Shetter, J. D., Allwine, E. J., and Westberg, H. H.: Observations and Modeling of the Reactive Nitrogen Photochemistry at a Rural Site, J. Geophys. Res., 96, 3045-3063, 1991. 
Tuazon, E. C., Alvarado, A., Aschmann, S. M., Atkinson, R., and Arey, J.: Products of the gas-phase reactions of 1,3-butadiene with $\mathrm{OH}$ and $\mathrm{NO}_{3}$ radicals, Environ. Sci. Technol., 33, 35863595, 1999.

von Kuhlmann, R., Lawrence, M. G., Pöschl, U., and Crutzen, P. J.: Sensitivities in global scale modeling of isoprene, Atmos. Chem. Phys., 4, 1-17, 2004, http://www.atmos-chem-phys.net/4/1/2004/.

Warneke, C., de Gouw, J. A., Goldan, P. D., Kuster, W. C., Williams, E. J., Lerner, B. M., Brown, S. S., Stark, H., Aldener, M., Ravishankara, A. R., Roberts, J. M., Marchewka, M., Bertman, S., Sueper, D. T., McKeen, S. A., Meagher, J. F., and Fehsenfeld, F. C.: Comparison of day and nighttime oxidation of biogenic and anthropogenic VOCs along the New England coast in summer during New Enlgand Air Quality Study 2002, J. Geophys. Res., 109, D10309, doi:10.1029/2003JD004424, 2004.
Weber, R. J., Orsini, D., Daun, Y., Lee, Y.-N., Klotz, P. J., and Brechtel, F.: A particle-into-liquid collector for rapid measurement of aerosol bulk chemical composition, Aerosol Sci. Technol., 35, 718-727, 2001.

Weber, R. J., Sullivan, A. P., Peltier, R., Russell, A., Yan, B., Zheng, M., de Gouw, J. A., Warneke, C., Brock, C. A., Holloway, J. S., Atlas, E. L., and Edgerton, E.: A study of secondary organic aerosol formation in the anthropogenicinfluenced southeastern United States, J. Geophys. Res., 112, D13302, doi:10.1029/2007JD008408, 2007.

Werner, G., Kaster, J., Looser, R., and Ballschmitter, K.: Organic Nitrates of Isoprene as Atmospheric Trace Compounds, Angew. Chem. Int. Ed., 38, 1634-1637, 1999.

Winer, A. M., Atkinson, R., and Pitts, J. N. J.: Gaseous Nitrate Radical: Possible Nighttime Atmospheric Sink for Biogenic Organic Compounds, Science, 224, 156-158, 1984. 